Review

\title{
West Nile Virus Drug Discovery
}

\section{Siew Pheng Lim and Pei-Yong Shi *}

Novartis Institute for Tropical Diseases, 10 Biopolis Road, Chromos 05-01, Singapore 138670, Singapore; E-Mail: siew_pheng.lim@novartis.com

* Author to whom correspondence should be addressed; E-Mail: pei_yong.shi@novartis.com; Tel.: +65-67222909; Fax: +65-67222916.

Received: 3 October 2013; in revised form: 25 November 2013 / Accepted: 25 November 2013 / Published: 3 December 2013

\begin{abstract}
The outbreak of West Nile virus (WNV) in 1999 in the USA, and its continued spread throughout the Americas, parts of Europe, the Middle East and Africa, underscored the need for WNV antiviral development. Here, we review the current status of WNV drug discovery. A number of approaches have been used to search for inhibitors of WNV, including viral infection-based screening, enzyme-based screening, structure-based virtual screening, structure-based rationale design, and antibody-based therapy. These efforts have yielded inhibitors of viral or cellular factors that are critical for viral replication. For small molecule inhibitors, no promising preclinical candidate has been developed; most of the inhibitors could not even be advanced to the stage of hit-to-lead optimization due to their poor drug-like properties. However, several inhibitors developed for related members of the family Flaviviridae, such as dengue virus and hepatitis $\mathrm{C}$ virus, exhibited cross-inhibition of WNV, suggesting the possibility to re-purpose these antivirals for WNV treatment. Most promisingly, therapeutic antibodies have shown excellent efficacy in mouse model; one of such antibodies has been advanced into clinical trial. The knowledge accumulated during the past fifteen years has provided better rationale for the ongoing WNV and other flavivirus antiviral development.
\end{abstract}

Keywords: drug discovery; antiviral; West Nile virus; flavivirus 
Abbreviations: DENV, dengue virus; WNV, West Nile virus; YFV, yellow fever virus; TBEV, tick-borne encephalitis virus; $\mathrm{HCV}$, hepatitis $\mathrm{C}$ virus; WEEV, Western equine encephalitis virus; VSV, vesicular stomatitis virus; HBV, hepatitis B virus; HIV, human immunodeficiency virus; DAA, direct antiviral agent; GTase, guanylyltransferase; PI, protease inhibitors; HTS, high-throughput screening; MTase, methyltransferase; RdRp, RNA-dependent RNA polymerase; NI, nucleoside analog inhibitor; NNI, non-nucleoside inhibitor; TI, therapeutic index; SAR, structure-activity relationship; ER, endoplasmic reticulum.

\section{Introduction}

West Nile virus (WNV) has an enveloped virion of about $50 \mathrm{~nm}$ in diameter, and comprises a lipid bilayer that surrounds a nucleocapsid with a single-stranded, positive-sense RNA genome of approximately 11,000 nucleotides. Both the 5' and 3' noncoding regions of the genome form extensive secondary structures, which are important for translation, RNA synthesis, and packaging [1-3]. The viral RNA is translated as a single polyprotein that is post- and co-translationally cleaved by both host and viral proteases to form three structural (capsid, envelope, and pre-membrane) and seven nonstructural (NS1, NS2A, NS2B, NS3, NS4A, NS4B, and NS5) proteins [4]. The envelope (E) protein is involved in receptor interaction, membrane fusion, and virion assembly. The pre-membrane (prM) stabilizes the conformation of $\mathrm{E}$ during virion assembly and protects $\mathrm{E}$ from undergoing premature fusion during virus exocytosis to the cell surface. The capsid (C) protein encapsidates the viral genome during assembly. Viral replication and assembly takes place in the cytoplasm, with budding in the endoplasmic reticulum (ER). The nonstructural proteins together form the replication complex needed for viral RNA synthesis and virion formation. NS1 glycoprotein is anchored to the cell surface and also secreted. It plays a role in replication although its exact role is not fully determined [5]. There is also evidence that NS1 is involved in neuroinvasiveness of WNV [6]. NS3 is a multi-functional protein that has protease, helicase, and NTPase activities. NS3 protease acts together with NS2B, is responsible for cleaving other nonstructural proteins from the viral polyprotein. NS5 protein encodes the viral methyltransferase (MTase) and RNA-dependent RNA polymerase (RdRp). NS4A induces membrane rearrangements, which are important for formation of the viral replication complex [7]. Several of the nonstructural proteins, including NS2A, NS2B, NS4A, and NS4B, are transmembrane proteins that have no identified enzymatic activities, but are essential for formation of the active replication complex [8,9]. They have also been shown to inhibit one or more components of the innate immune response against viral infection [10].

There are currently no marketed drugs or clinical candidates for treatment or prevention of flavivirus (including WNV) infection in humans. This article reviews the latest development in WNV drug discovery and the challenges/opportunities ahead.

\section{Approaches to Identify Antiviral Inhibitors}

Effective antiviral therapy for WNV may target either viral (structural and non-structural) or host proteins that are essential for WNV infection or replication. Small molecule-based inhibitors can be identified using the following approaches. (i) HTS (high-throughput screening) using virus replication 
assays; (ii) HTS using viral enzyme assays; (iii) structure-guided in silico docking and rational design; (iv) Repurposing other viral inhibitors for WNV. It is envisaged that inhibitory compounds that act on related flaviviruses, such as dengue virus (DENV) or hepatitis $\mathrm{C}$ virus (HCV) may also be effective on WNV. There are some examples with pan-active flavivirus entry, protease, MTase, and RdRp (nucleoside) inhibitors. Many of the drug screening and design efforts against WNV have thus far centered on the viral protease, with fewer endeavors directed at the other viral enzymatic activities, such as the RdRp or MTase. Non-structural proteins with no enzymatic activities (NS2A, NS4A, and NS4B) could also be targeted for antiviral development, as demonstrated by the success of HCV NS5A inhibitor currently in clinical trial [11].

Besides small molecule-based inhibitors, therapeutic antibodies have been vigorously pursued for WNV treatment. So far, therapeutic antibodies represent the most promising approach. This approach has not only produced candidates in clinical trial for treatment of WNV infection, but also helped to understand antibodies that are needed for an effective flavivirus vaccine.

\section{Inhibitors of Viral Targets}

\subsection{Viral Entry Inhibitors}

Entry inhibitors prevent virus from attachment to cell, entering into cell, or virus-host membrane fusion. Flavivirus E protein's major conformational changes and well-defined molecular structures, both pre- and post-fusion, are potentially amenable to inhibitor design [12-14]. In particular, the crystal structure of the DENV2 E protein displays a ligand-binding pocket that was occupied by a detergent molecule, n-octyl-b-D-glucoside (b-OG) [15]. This initiated several groups to identify and optimize potential inhibitors targeting this region of E protein for DENV [16-20] and YFV [21-23], mainly through a virtual screening approach. Although different classes of compounds were identified that inhibited DENV, only a handful worked on WNV. One compound (compound 5) was reported to exhibit anti-DENV2 and WNV activities with $\mathrm{EC}_{50}$ values of $1.2 \pm 0.7$ and $3.8 \pm 2.9 \mu \mathrm{M}$ respectively [20]. From a virtual screening campaign, another compound (compound 1), belonging to the quinazoline scaffold, demonstrated a broad spectrum anti-flavivirus activity [19]; further optimization resulted in compound 6 with submicromolar activities against both DENV1-4 and WNV. Despite efforts to improve the pharmacokinetic properties, its low solubility prevented further development.

Besides small molecule inhibitors, protein- and peptide-based inhibitors have also been pursued to inhibit WNV entry. One group demonstrated that recombinant domain III from WNV E protein inhibited WNV entry into Vero cells and C6/36 mosquito cells [24]. Short peptides (25-33 aa) derived from DENV and WNV envelope protein sequences can inhibit DENV2 and WNV infection in cell culture with $\mathrm{EC}_{50}$ of about $10 \mu \mathrm{M}$ [25]. The drawback of peptidic inhibitors is the need for intravenous administration and its limited shelf life, which limits their use in clinical settings, especially in developing countries.

\subsection{Therapeutic Antibody}

The therapeutic antibody represents the most promising class of WNV entry inhibitors among all the current antiviral approaches. Antibodies can protect against flavivirus infection through several 
mechanisms, including blockage of receptor binding, inhibition of viral fusion, Fc- $\gamma$ receptor-dependent viral clearance, complement-mediated lysis of virus or infected cells, and antibody-dependent cytotoxicity of infected cells. Readers are encouraged to read an excellent recent review on this topic [26]. Small numbers of clinical studies showed that patients with neuroinvasive WNV infection improved after receiving immune $\gamma$-globulin from Israeli donors who were serum-positive against WNV [2730]. These clinical results encourage the development of human or humanized monoclonal antibodies for treatment of WNV infection. Indeed, potent monoclonal antibody fragments have been developed against WNV. Mice and hamsters infected with WNV were protected after a single-dose treatment of such antibody on day 5 or 6 post infection [31-33]. A phase I clinical trial completed in 2009, determined that a potent antibody (derived from E16 antibody, also known as MGAWN1 was safe and well tolerated in healthy subjects as single infusions up to $30 \mathrm{mg} / \mathrm{kg}$. Unfortunately, a phase II trial to assess its efficacy in severe WNV infection in humans was terminated prematurely due to poor patient enrollment.

\subsection{NS3}

NS3 is a multifunctional protein, consisting of the $N$-terminal serine protease domain localized to amino acids 1-169 and the $C$-terminal domain from residues 180-618, bearing helicase, nucleoside triphosphatase, and RNA triphosphatase activities [34-36]. The $N$ and $C$-terminal domains are linked via a flexible inter-domain, comprising residues 169-179 of NS3 [37,38]. Along with other flaviviruses, the crystal structures of the WNV protease and helicase domains have been resolved ([3943]; Figure 1). Full-length NS3 has increased ATP binding and helicase activity compared to the helicase domain alone [40], but no enhancement of the protease activity compared to the protease domain alone [37]. One group found that the functional NS2B/3 protease did not influence helicase activity [40], whilst another group found that it represses helicase unwinding activity [44]. Both the ATPase and helicase activities of NS3 have been shown to be regulated by NS4A [45], and the two activities can function independently of each other [46]. Within infected host cells, these functions appear to be regulated by their differential localization to separate virus-induced membranous compartments [47].

\subsubsection{NS3 Protease}

WNV NS3 protease, like the counterpart from other members of the flaviviruses, is activated by its membrane associated co-factor, the NS2B protein [48,49]. Besides cleaving the junctions between the viral proteins, cleavage of host proteins by WNV NS2B/3pro has been proposed to contribute to neuro-pathogenesis [50-52]. Therapeutic strategies for viral proteases have been successfully exemplified by ten HIV-1 protease inhibitors (PIs; [53]) and two recent HCV protease inhibitors [54]. Thus, protease inhibitors against flaviviruses would also likely be efficacious in the clinic and have been intensely pursued. Nevertheless, in both HIV-1 and HCV patients, rapid emergence of PI drug-resistant viruses due to expansion of pre-existing naturally resistant variants [55-57] have been observed and is the reason to be cautious about this approach. Although WNV disease is primarily acute in nature, chronic and persistent infections in humans [58] with serious long-term sequelae have also been reported [59-61]. Fortunately, sequence similarity across WNV lineages 1 and 2 for NS3 
protease region is greater than $96 \%$, implying that genetic barrier to any naturally occurring mutant WNV variants would be higher than for HCV or HIV-1 where the protease sequences are much less conserved.

Figure 1. Crystal structures of West Nile Virus (WNV) NS2/NS3 protease and NS3 helicase domains depicted in cartoon representation. (a) WNV NS2B/3 protease bound to the peptidic inhibtor, nKRR-H inhibitor [PDB code 2FP7; 39]. NS3 is colored green. $\mathrm{NS} 2 \mathrm{~B}$ is shown in red ( $N$-terminal region) and yellow ( $C$-terminal region). Bz-nKRR-H (pink) is shown in stick representation. Locations of $\mathrm{S} 1$ and $\mathrm{S} 2$ pockets are marked with arrows; (b) WNV NS3 helicase with domains 1, 2 and 3 colored in cyan, green and orange, respectively [PDB code 2QEQ; 40].

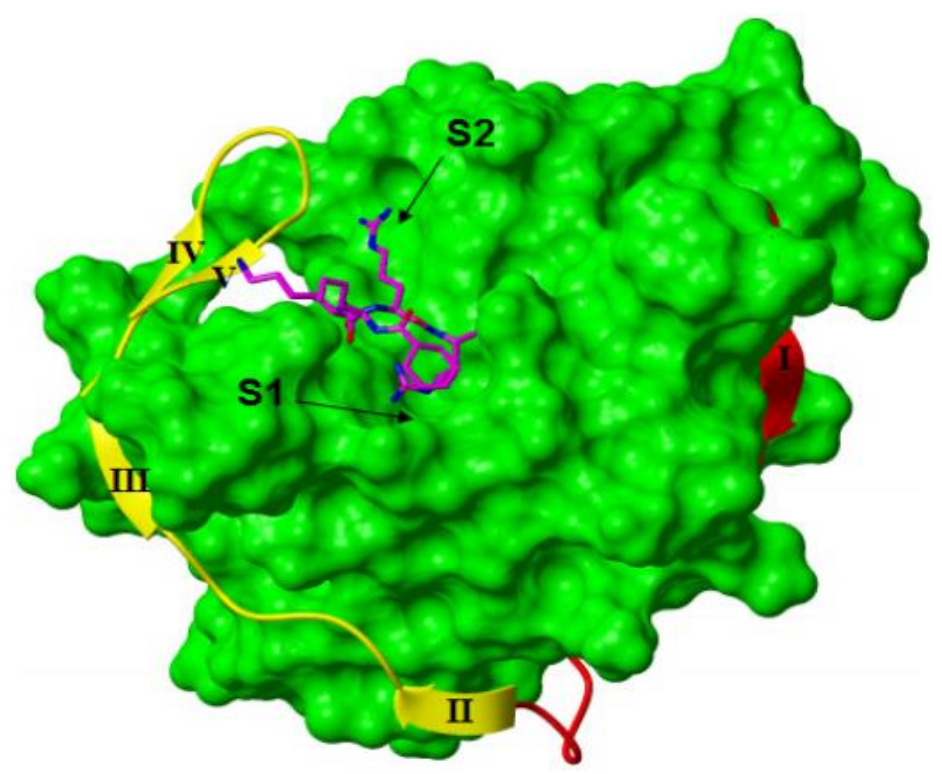

(a)

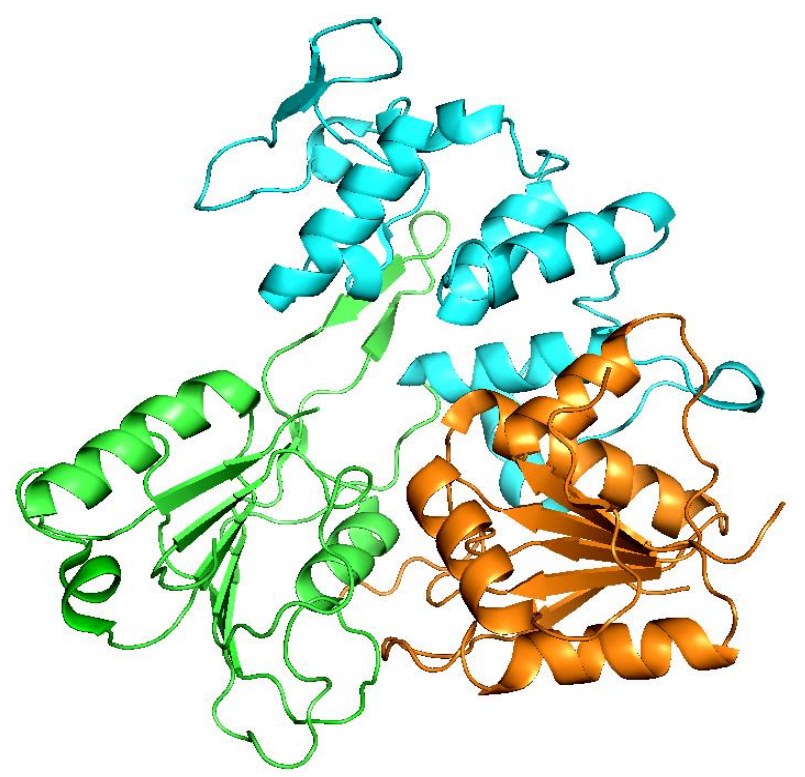

(b) 
Table 1. List of WNV NS2B/3pro peptidic inhibitors.

\begin{tabular}{|c|c|c|c|c|c|}
\hline Compound & WNV Ki $(\mu \mathrm{M})$ & Binding Mode & $\begin{array}{c}\text { Co-crystallised with WNV } \\
\text { NS2B/3pro }\end{array}$ & $\begin{array}{c}\text { Anti-WNV } \\
\text { cellular activity }\end{array}$ & Ref \\
\hline Aprotinin & $0.026 ; 0.09 \pm 0.02$ & non-covalent & 34 & & {$[73,74]$} \\
\hline Bz-Nle-KRR-H & 4.1 & covalent; warhead & 31 & & [70] \\
\hline Bz-Nle-KKR-H & 1.9 & covalent; warhead & & & [70] \\
\hline Bz-Nle-KR(p-guanidinyl)F-H & 12 & covalent; warhead & & & [70] \\
\hline rrrrrr-NH2 (hexa-D-R-NH2) & 0.478 & non-covalent & & & [75] \\
\hline rrrrrrr-NH2 (hepta-D-R-NH2) & 0.041 & non-covalent & & & [75] \\
\hline rrrrrrrr-NH2 (octa-D-R-NH2) & 0.017 & non-covalent & & & [75] \\
\hline rrrrrrrrrr-NH2 (nona-D-R-NH2) & 0.006 & non-covalent & & yes & [75] \\
\hline rrrrrrrrrr-NH2 (deca-D-R-NH2) & 0.002 & non-covalent & & & [75] \\
\hline rrrrrrrrrrrr-NH2 (undeca-D-R-NH2) & 0.001 & non-covalent & & & [75] \\
\hline rrrrrrrrrrrr-NH2 (dodeca-D-R-NH2) & 0.001 & non-covalent & & & [75] \\
\hline 2-naphthoyl-KKR-H & 0.041 & covalent; warhead & 33 & & [71] \\
\hline phenylacetyl-KKR-H & $0.009 ; 0.70 \pm 0.04$ & covalent; warhead & & yes & {$[71,72]$} \\
\hline 4-phenylphenylacetyl-KKR-H & $0.006 ; 0.056 \pm 0.004$ & covalent; warhead & & & {$[71,72]$} \\
\hline acetyl-KKR-H & $0.49 \pm 0.32$ & covalent; warhead & & & [72] \\
\hline propionyl-KKR-H & $0.43 \pm 0.06$ & covalent; warhead & & & [72] \\
\hline cyclopropionyl-KKR-H & $0.19 \pm 0.01$ & covalent; warhead & & & [72] \\
\hline benzoyl-KKR-H & $0.21 \pm 0.09$ & covalent; warhead & & & [72] \\
\hline acetyl-KR-H & $0.09 \pm 0.02$ & covalent; warhead & & & [76] \\
\hline propionyl-KR-H & $0.17 \pm 0.06$ & covalent; warhead & & & [76] \\
\hline cyclopropionyl-KR-H & $0.22 \pm 0.05$ & covalent; warhead & & & [76] \\
\hline benzoyl-KR-H & $0.92 \pm 0.09$ & covalent; warhead & & & [76] \\
\hline acetyl-Lys-Lys-agmatine & $9.1 \pm 2.1$ & non-covalent & & & [77] \\
\hline 4-phenylphenylacetyl-Lys-Lys-agmatine & $2.05 \pm 0.13$ & non-covalent & & & [77] \\
\hline 2-chloro-4-phenyl-phenacetyl-L-Lys-Lys-agmatine & $1.3 \pm 0.2$ & non-covalent & & & [78] \\
\hline 4-chloro-4-phenyl-phenacetyl-L-Lys-Lys-agmatine & $2.4 \pm 0.5$ & non-covalent & & & [78] \\
\hline 2-methyl-4-phenyl-phenacetyl-L-Lys-Lys-agmatine & $3.4 \pm 0.6$ & non-covalent & & & [78] \\
\hline 4-methyl-4-phenyl-phenacetyl-L-Lys-Lys-agmatine4 & $3.5 \pm 0.7$ & non-covalent & & & [78] \\
\hline
\end{tabular}


Due to the large amount of structural, biochemical, and functional information garnered on this enzyme over the past decade (refer to [62-65] for excellent reviews on these topics), many researchers have taken either a rational design approach to find inhibitors via substrate mimicry or utilized in silico docking methodologies (Table 1). The challenges with the peptidomimetics approach for WNV protease are the shallow active site and the apparent flexibility of NS2B residues that contribute to the active site, as shown by the apo- and inhibitor-bound crystal structures ([39,41-43,66]; Figure 1) as well as NMR structures of this enzyme [67-69]. There is also a need to replace the two conserved basic P1 and P2 residues of the substrate cleavage site (P1-Arg and P2-Lys). Thus far, no group has demonstrated any success in this area. In general, researchers have been able to design more potent peptidic inhibitors against WNV protease compared to DENV protease. Single or double digit nano-molar inhibitors have been reported for the former, whilst none has been found for DENV protease.

As observed by earlier reports, selectivity among DENV, YFV, and WNV proteases may be achieved through the P2 site whereby the WNV enzyme prefers Lys over Arg. Substituents that increase the bulkiness of the P2-Lys group are also not accommodated [70-72]. Two highly potent peptidic inhibitors were reported to have cellular anti-WNV activity ([71,75]; Table 1). However, the physiochemical and pharmacokinetic properties of both nona-D-R-NH2 and phenylacetyl-KKR-H make them unsuitable drug candidates as they are highly charged (presence of large numbers of Arg residues), lack specificity (aldehyde warhead is highly reactive and nonspecific), and would also be rapidly degraded in plasma. Interestingly, di-peptidic aldehyde inhibitors with small caps exhibit improved potencies compared to their tripeptide counterparts ([76]; Table 1). One of the most potent inhibitor is a simple di-peptide, acetyl-KR-H, with Ki of $90 \mathrm{nM} \mathrm{[76].} \mathrm{This} \mathrm{inhibitor} \mathrm{may} \mathrm{be} \mathrm{a} \mathrm{good}$ starting point for peptidomimetics. Recently, several non-covalent peptide inhibitors with P1 decarboxylated arginine (agmatine; 4-aminobutylguanidine) were designed and tested against WNV protease ([77,78]; Table 1]. Interestingly, for this class of inhibitors, di-peptide with bulky aromatic caps are more potent than those with small caps, which suggest that in the absence of a warhead, interactions beyond S1 and S2 subsites contribute more significantly to the binding affinity. Whilst promising, this class of inhibitor still retains the highly charged nature of the covalent peptidic inhibitors.

Nitsche et al. [79] reported the generation of 3-aryl-2-cyanoacrylamide compounds, which are not based on substrate mimetics. These compounds exhibited double-digit micromolar activities against WNV and DENV proteases; their binding specificity was demonstrated using a competition assay with aprotinin. The advantages of these compounds are the high ligand efficiency and the possibility to "grow" them to improve their potency.

One final consideration for development of WNV protease inhibitors is the need to possess selectivity over other arginine-specific host proteases such as trypsin, thrombin, factor Xa, and furin. Nevertheless, much progress has been made to generate selective inhibitors to these various human enzymes. Dabigatran is a highly potent inhibitor of thrombin that was generated through structure guided design [80], whilst Rivaroxaban is a nonpeptide inhibitor against FactorXa that was identified from a screening campaign [81]. With perseverance, it would be a matter of time before success can be achieved too in WNV protease inhibitors. 
Table 2. List of WNV NS2B/3pro non-peptidic inhibitors.

\begin{tabular}{|c|c|c|c|c|c|c|}
\hline Compound (Substrate) & Core & Method & $\begin{array}{l}\text { WNV IC } \\
\quad(\mu \mathrm{M})\end{array}$ & $\begin{array}{c}\text { Biophysical } \\
\text { method }\left(K_{d}, \mu M\right)\end{array}$ & $\begin{array}{c}\text { Anti-WNV cellular } \\
\text { activity } \mathrm{EC}_{50}\left[\mathrm{CC}_{50}\right] \text { in } \mu \mathrm{M}\end{array}$ & Ref \\
\hline $\begin{array}{c}\text { cpd A } \\
\text { (Boc-GKR-AMC) }\end{array}$ & 8-hydroxyquinoline & Diverse library screening & $6.4 \pm 0.6$ & & & [82] \\
\hline $\begin{array}{c}\text { cpd B } \\
\text { (Boc-GKR-AMC) }\end{array}$ & 8-hydroxyquinoline & Diverse library screening & $\begin{array}{l}6.8 \pm 1.2 \\
3.6 \pm 2.0\end{array}$ & & $\begin{array}{c}1.4 \pm 0.4 \\
{[140 \pm 1.98]}\end{array}$ & {$[82,83]$} \\
\hline Compound 14 & 8-hydroxyquinoline & Derivatization of cpd B & $\begin{array}{c}1.0 \pm 0.08 \\
(\mathrm{GKR}-\mathrm{AMC}) \\
2.01 \pm 0.08 \\
(\mathrm{nkRR}-\mathrm{AMC})\end{array}$ & & & [83] \\
\hline $\begin{array}{c}\text { Compound } 12 \mathrm{j} \\
\text { (Boc-GKR-AMC) }\end{array}$ & 1-oxo-1,2-dihydroisoquinoline & $\begin{array}{c}\text { Focus library } \\
\text { design and screening }\end{array}$ & 30 & & & [84] \\
\hline $\begin{array}{c}\text { Palmatine } \\
\text { (pERTKR-AMC) }\end{array}$ & natural product & unknown & 96 & & $3.6[1031]$ & [85] \\
\hline cpd 1 (nKRR-AMC) & Carbamimidoylsulfanyl-methyl & In silico FBS & 178 & NMR (40) & & [86] \\
\hline cpd 1 (nKRR-AMC) & & In silico $\mathrm{FBS}$ & $2.8 \pm 0.1$ & $\begin{array}{c}\text { NMR } \\
(90 \pm 40)\end{array}$ & & [87] \\
\hline cpd 1 (nKRR-AMC) & & In silico $\mathrm{FBS}$ & $34.2 \pm 0.1$ & & & [87] \\
\hline $\begin{array}{c}\text { SID-852843 } \\
\text { (Pyr-RTKR-AMC) }\end{array}$ & pyrazolyl benzoic acid ester & Diverse library screening & 0.105 & & & [88] \\
\hline $\begin{array}{c}\text { SID-4245669 } \\
\text { (Pyr-RTKR-AMC) }\end{array}$ & pyrazolyl benzoic acid ester & Diverse library screening & 0.11 & & & [88] \\
\hline $\begin{array}{c}\text { SID-3717586 } \\
\text { (Pyr-RTKR-AMC) }\end{array}$ & pyrazolyl benzoic acid ester & Diverse library screening & 1.353 & & & [88] \\
\hline $\operatorname{cpd} 7 \mathrm{a}$ & & Derivatization of pyrazole ester & 1.96 & & & [89] \\
\hline cpd 10a & & Derivatization of pyrazole ester & 4.03 & & & [89] \\
\hline $\begin{array}{l}\text { cpd 4; } 166347 \\
\quad(\text { FRET })\end{array}$ & $\begin{array}{c}\text { guanidinylated } \\
\text { 2,5-dideoxystreptamine }\end{array}$ & Diverse library screening & $1.2 \pm 0.3$ & & & [74] \\
\hline
\end{tabular}


Table 2. Cont.

\begin{tabular}{|c|c|c|c|c|c|c|}
\hline Compound (Substrate) & Core & Method & $\begin{array}{c}\text { WNV IC50 } \\
(\mu \mathrm{M})\end{array}$ & $\begin{array}{c}\text { Biophysical } \\
\operatorname{method}(\mathrm{Kd}, \boldsymbol{\mu M})\end{array}$ & $\begin{array}{c}\text { Anti-WNV cellular } \\
\text { activity EC50 [CC50] in } \mu M\end{array}$ & Ref \\
\hline $\begin{array}{l}\text { cpd 9; } 166550 \\
\text { (FRET) }\end{array}$ & $\begin{array}{c}\text { guanidinylated } \\
\text { 2,5-dideoxystreptamine }\end{array}$ & Diverse library screening & $4 \pm 2$ & & & [74] \\
\hline $\begin{array}{l}\operatorname{cpd} 7 ; 166346 \\
\quad(\text { FRET })\end{array}$ & $\begin{array}{c}\text { guanidinylated } \\
\text { 2,5-dideoxystreptamine }\end{array}$ & Diverse library screening & $6 \pm 1$ & & & [74] \\
\hline $\begin{array}{l}\text { cpd } 2 ; 166750 \\
\quad(\text { FRET })\end{array}$ & $\begin{array}{c}\text { guanidinylated } \\
\text { 2,5-dideoxystreptamine }\end{array}$ & Diverse library screening & $8 \pm 1$ & & & [74] \\
\hline $\begin{array}{l}\text { cpd 6; } 166631 \\
\text { (FRET) }\end{array}$ & $\begin{array}{c}\text { guanidinylated } \\
\text { 2,5-dideoxystreptamine }\end{array}$ & Diverse library screening & $8 \pm 1$ & & & [74] \\
\hline $\begin{array}{c}\text { cpd 1a24 } \\
\text { (Pyr-RTKR-AMC) }\end{array}$ & $\begin{array}{c}2-\{6-[2-(5-\text { phenyl-4H- } \\
{[1,2,4] \text { triazol-3- }} \\
\text { ylsulfanyl)acetylamino]- } \\
2-\{6-[2-(5-\text { phenyl-4H- } \\
{[1,2,4] \text { triazol-3- }} \\
\text { ylsulfanyl)acetylamino]- } \\
\text { benzothiazol-2- } \\
\text { ylsulfanyl }\} \text { acetamide }\end{array}$ & Diverse library screening & $3.4 \pm 0.2$ & & & [90] \\
\hline $\begin{array}{c}\text { cpd 1a16 } \\
\text { (Pyr-RTKR-AMC) }\end{array}$ & $\begin{array}{l}\text { 1,3,4,5-tetrasubstituted } \\
\text { 1H-pyrrol-2(5H)-one }\end{array}$ & Diverse library screening & $2.2 \pm 0.7$ & & & [91] \\
\hline $\begin{array}{c}\text { cpd 1a40 } \\
\text { (Pyr-RTKR-AMC) }\end{array}$ & $\begin{array}{l}\text { 9,10-dihydro-3H,4aH-1,3,9,10a- } \\
\text { tetraazaphenanthren-4-one }\end{array}$ & Diverse library screening & $2.2 \pm 0.7$ & & & [92] \\
\hline Tyrothricin (M23) & decapolypeptide antibiotic & Diverse library screening & $2 \pm 0.2$ & & & [93] \\
\hline $\begin{array}{l}\text { Cpd 1; NSC86314 } \\
\text { (Pyr-RTKR-AMC) }\end{array}$ & & In silico docking & 0.26 & & $42.77[212.5]$ & [94] \\
\hline $\begin{array}{l}\text { Cpd 2; NSC16898 } \\
\text { (Pyr-RTKR-AMC) }\end{array}$ & & In silico docking & 0.44 & & $17.01[235.8]$ & [94] \\
\hline
\end{tabular}


HTS using in vitro WNV protease biochemical assays as well as in silico docking of compounds into the WNV protease structure have also been actively pursued (Table 2). The advantage of these methods is the potential to find allosteric inhibitors that block NS2B/3 interaction or bind outside of the NS3 active site. A number of inhibitors have been identified, but majority of them show micromolar activities in the enzyme assays without biophysical confirmation of their binding specificity. Even fewer demonstrated anti-WNV activity in cell-based assays. This raises the possibility that some of these hits may be non-specific. The exceptions are fragments identified by in silico docking which were shown to bind to the protease by NMR [86,87]. Two highly potent classes of compounds were reported to have submicromolar inhibitory activities in the in vitro biochemical assays $[88,94]$, with selectivity over DENV2 protease and furin, as well as anti-WNV cellular activity [94]. However, the $\mathrm{EC}_{50}$ value has not been shown to be a consequence of on-target inhibition inside the cells. One way to confirm this is to raise resistant WNV against the inhibitors. Unfortunately, none of the published inhibitors have been reported to progress beyond the hit optimization phase. This is probably in part due to the difficulties in obtaining co-crystal structures of these inhibitors bound to the WNV protease, probably due to the flexible NS2B. Devising means for generation of robust co-crystals will pave the way forward for identification of WNV inhibitors. Although many researchers docked the hits into the enzyme active site to assess their binding modes and design analogs for SAR studies, this approach has not proven to be fruitful.

\subsubsection{NS3 Helicase}

The $C$-terminal of flavivirus NS3 encompasses helicase, NTPase, and RTPase activities. Adaptive amino acid changes in the WNV helicase have been implicated in virus transmissibility and pathogenesis. A substitution of amino acid T249P in the NS3 helicase (found in North American WNV) in a low-virulence strain was sufficient to generate a phenotype highly virulent to American crows [95]. Furthermore, a virus strain with a S365G mutation in the helicase domain was shown to overcome the host interferon response. This mutation modulated the ATPase activity of NS3 and enabled it to subvert Oas1b-mediated suppression of viral RNA accumulation [96].

Much more efforts had been made to identify inhibitors to WNV helicase compared to efforts for other flavivirus helicase. Nevertheless, similar to the disappointing experiences for WNV protease, WNV inhibitors have also not progressed beyond the hit-to-lead finding phase. In many cases, there was also no report of anti-WNV activity of these compounds in cell culture. An in silico screening campaign using the WNV (Kunjin) helicase found that ivermectin potently inhibited the dsRNA unwinding activity of WNV helicase with $\mathrm{IC}_{50}$ values between 200-400 nM [97]. No inhibition of NS3 ATPase or NS5 RdRp activity was observed. Production of infectious WNV was also affected $\left(\mathrm{EC}_{50}=4 \mu \mathrm{M}\right)$ and time of addition experiments suggest ivermectin works during viral replication. Ivermectin has been used extensively for more than twenty years, as a broad-spectrum, oral drug against parasitic infections [98]. More recently, it was also shown to inhibit DENV1-4 replication, most likely through interfering with NS5 nuclear translocation $[99,100]$. Whilst interesting, more work needs to be done to further ascertain the efficacy of ivermectin against flavivirus-associated diseases, such as in vivo testing in relevant small animal models, confirmation of direct effect(s) on viral replication, and generation of ivermectin-resistant viruses. Nevertheless, evaluation of antiviral activity 
of already approved drugs such as ivermectin could streamline pathways to clinical evaluation compared to development of entirely new compounds (See also Section 4 on cyclophilins and Celgosivir).

By randomly screening peptides derived from the helicase protein, Browoski et al. [101] found that a basic peptide comprising motif VI (amino acids 1487-1500) of HCV helicase inhibited the unwinding activity of $\mathrm{HCV}, \mathrm{WNV}$, and JEV helicases, without affecting their NTPase activity. Interestingly, WNV helicase is more strongly inhibited by the HCV motif VI peptide $\left(\mathrm{IC}_{50}=2.7 \pm 0.3 \mu \mathrm{M}\right)$ compared to its endogenous counterpart $(156 \pm 6.9 \mu \mathrm{M})$. Whilst these peptides may serve as good tools for characterising the enzyme in vitro, it may be difficult to develop them further as drug candidiates due to permeability and stability liabilities.

Several classes of compounds were synthesized and evaluated for inhibitory activity against WNV helicase. However, as they showed differential inhibitory properties depending on whether an RNA or DNA substrate was used, it casts some doubts on the specificity of their inhibitory properties. For example, analogues of 1H-benzotriazole, 1H-benzimidazole, as well as AICAR (4-carbamoyl-5-(4,6diamino-2,5-dihydro-1,3,5-triazin-2-yl)imidazole-1-beta-D-ribofuranoside) exerted good $\mathrm{HCV}$ and WNV helicase inhibitory activity when DNA was used as substrate. However, the activity was strongly decreased or even disappeared when RNA was used as a substrate [102,103]. Furthermore, a diverse library screen resulted in 5,6-dichloro-1-(beta-d-ribofuranosyl)benzotriazole (DRBT) which has good and selective inhibition of WNV helicase with an RNA substrate ( $\mathrm{IC}_{50} \sim 0.3 \mu \mathrm{M}$ ), but much weaker with a DNA substrate $\left(\mathrm{IC}_{50} \sim 3 \mu \mathrm{M}\right)$ [104]. This discrepancy in the inhibitory properties of these compounds suggests that the unwinding assays for WNV helicase could be further optimized. Finally, 5'-O-(4-fluorosulphonylbenzoyl)-esters of inosine exhibited low inhibitory activity against WNV helicase $\left(\mathrm{IC}_{50}=70 \mu \mathrm{M}\right.$ with UTP substrate), but may not be specific as it was comparatively active against $\mathrm{HCV}$ polymerase $\left(\mathrm{IC}_{50}=80 \mu \mathrm{M}\right)$ [105].

A series of ring-expanded ("fat") nucleoside analogues (RENs) containing the 6-aminoimidazo[4,5-e] $[1,3]$ diazepine-4,8-dione ring system with long $\mathrm{C}(12), \mathrm{C}(14)$, or $\mathrm{C}(18)$ side-chains at position 6 were all found to have excellent profiles of activity and selectivity toward the viral versus cellular enzymes, with $\mathrm{IC}_{50}$ ranging between $1-10 \mu \mathrm{M}$ for $\mathrm{WNV}$ helicase. One ring-expanded heterocycle analogue, which contains aralkyl substitution at position 1 (compound 39), was equally potent but somewhat less selective; whereas compound 36, which is an alpha-anomeric counterpart of 30, exhibited potent and selective inhibition of WNV ( $\left.\mathrm{IC}_{50} 1-3 \mu \mathrm{M}\right)$. None of these compounds showed activity against the viral NTPase even up to $500 \mu \mathrm{M}$ [106]. Likewise, RENs containing imidazo[4,5-e][1,3]diazepine ring system (compounds 14 and 15) and imidazo[4,5-e][1,2,4]triazepine ring systems (compound 30c) gave single-digit micromolar actvities against WNV helicase in a DNA or RNA unwinding assay [107]. The triphosphate forms of some of these compounds also inhibited WNV NTPase activity. Selectivity was also obtained against HCV, JEV, or human helicases. However, none of these compounds described in the literature, except for ivermectin [97] and imidazo[4,5-d]pyridazine nucleosides [108], possessed anti-WNV activity in cell culture. Even so, it was not proven that the inhibition of virus replication by these nucleoside analogs was due to direct effect on WNV helicase activity. The ability to generate resistant viruses that mapped to the helicase protein sequence would have provided strong evidence for on-target inhibition of these compounds. 


\subsection{NS4B}

WNV NS4B is a small hydrophobic nonstructural protein that is hypothesized to participate in viral replication and evasion of host innate immune defenses [109]. Mutations in NS4B affect viral RNA replication [110-112], possibly through its interaction with NS3 helicase [113]. Several specific DENV-NS4B inhibitors have been identified through screening with whole-virus cell based assays $[113,114]$, but thus far only one inhibitor has been reported for WNV. Lycorine was found to reduce viral titers of WNV, DENV-1 and -2 , and YFV by $10^{2}-$ to $10^{4}$-fold when tested at $1.2 \mu \mathrm{M}$ concentration [115]. It exerted its antiviral activity mainly through suppression of viral RNA replication. WNV resistant to lycorine possessed a single amino acid substitution in V9M in the viral $2 \mathrm{~K}$ peptide (spanning the endoplasmic reticulum membrane between NS4A and NS4B proteins); this mutation increased viral RNA replication. Besides WNV and DENV, screening efforts also identified NS4B inhibitors that are selective for YFV [116].

\subsection{NS5}

NS5 is the most conserved protein amongst members of the genus Flavivirus and comprises the $N$-terminal MTase/GTase and the $C$-terminal RdRp. Separate crystal structures for several flavivirus MTase domains and RdRp domains have been solved and show very high structural homology (for reviews see [117-120]; Figure 2). Whilst both the capping and RdRp activities of NS5 are genetically validated to be essential for viral replication, only the RdRp activity can be considered as chemically validated, due to development of marketed drugs against viral polymerases such as for HIV-1 and HBV. Several polymerase inhibitors are currently in late phase clinical testing against the related $\mathrm{HCV}$. Whilst majority of $\mathrm{RdRp}$ inhibitors are nucleoside analogs acting through chain termination of viral RNA replication, non-nucleoside inhibitors are also prevalent. It remains to be seen if the flavivirus MTase can also be successfully targeted, since the core domains of MTases are evolutionarily well conserved. Designing flavivirus selective inhibitors which do not inhibit host MTases, i.e., RNA MTase, DNA MTase, protein MTase, or the SAM-binding protein, is potentially challenging. On the other hand, it is envisaged that the RdRp would pose fewer selectivity issues as there are no structurally homologous enzymes in the host cell.

\subsubsection{MTase and GTase}

WNV MTase performs sequential N-7 and 2'- $O$ methylation of the viral RNA to generate a type-1 cap structure (reviewed in [121]). WNV defective in N-7 methylation is non-replicative; whilst WNV defective in 2'-O methylation is attenuated and can protect mice from subsequent wild-type WNV challenge [122]. 2'- $O$ cap methylation also functions to subvert innate host antiviral response through modulation of the antiviral effects of a class of IFN-stimulated protein, the IFN-induced proteins with tetratricopeptide repeats (IFIT; [123]). This enzyme can further perform internal methylation of adenosines in the viral RNA genome at the ribose 2'-OH position [124]. Although binding of GTP and its analogues to the "GTP pocket" of flavivirus MTase domain has been shown for several different members of the family (reviewed in [117-120]), only two groups observed its GTase activity. Using radio-labeled GTP, they reported in vitro covalent attachment of GMP to Wesselsbron, DENV, YFV, 
and WNV MTase $[125,126]$. It has not been shown if such GMP-MTase covalent linkage is specific for GTP (i.e., if ATP, CTP or UTP has a similar activity). More work is required to definitively demonstrate the GTase activity of NS5. Collectively, these findings suggest that the dual N-7, 2'-O MTase/GTase is a potential target for flavivirus therapy.

Figure 2. Crystal structures of West Nile Virus (WNV) NS5 MTase and RdRp domains depicted in cartoon representation. (a) WNV MTase (light blue) in complex with sinefugin (pink in stick representation; PDB code 3LKZ). Sinefungin inhibits Flavivirus MTase N7 and 2' $O$ activities by competitively binding to the enzyme catalytic pocket $[121,128]$; (b) WNV NS5 RdRp domain (blue) bound with Zn (grey sphere) and $\mathrm{Mg}^{2+}$ (orange sphere) coordinated by Asp536 and 669 (not labeled) [139,143]. Thumb, fingers, and palm subdomains are indicated in red, green and blue (PDB code 2HFZ).

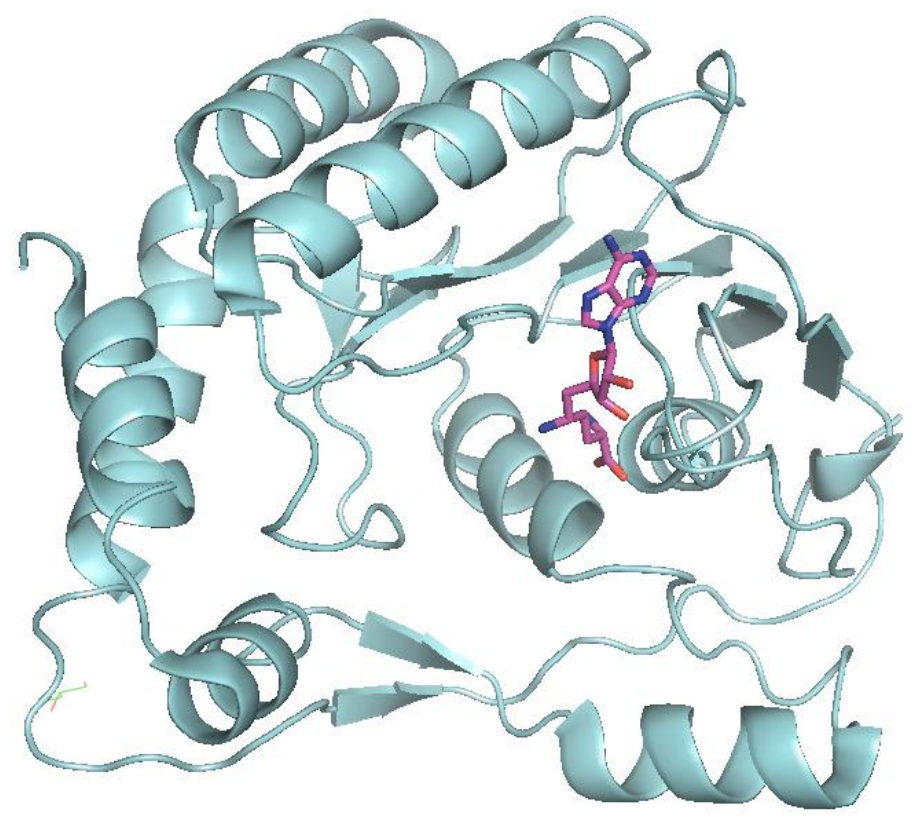

(a)

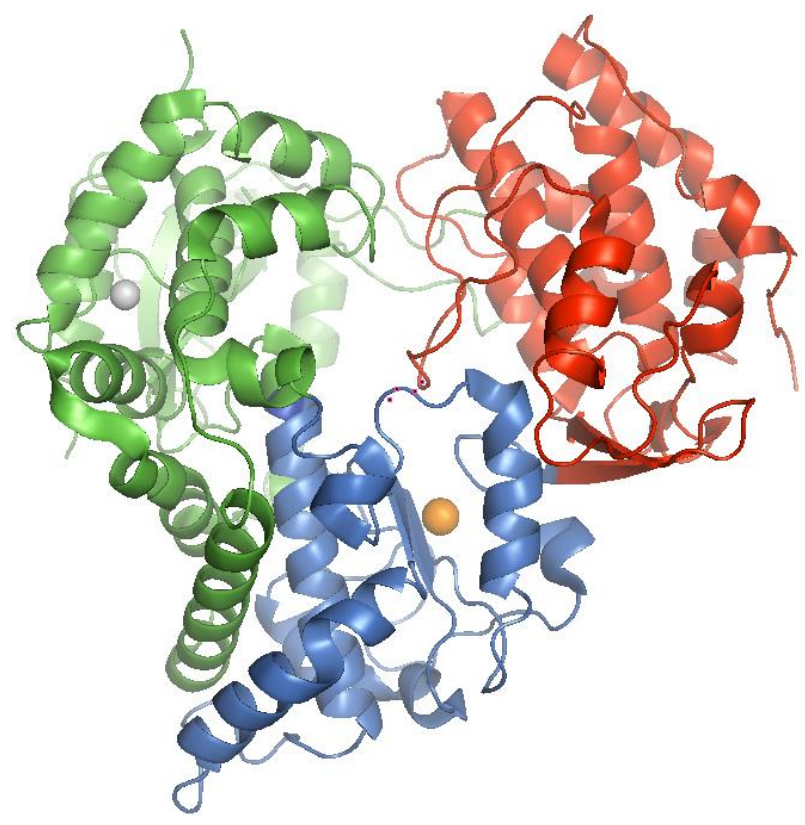

(b)

The wealth of structural information for NS5 MTase and RdRp domains has provided a solid foundation for structure-guided antiviral approaches. An extensive virtual screening campaign was performed by docking with more than 5 million commercial compounds into both the GTP-binding pocket and the active site of DENV MTase. Unfortunately, this exercise failed to yield any specific hits [127]. Taking advantage of a unique pocket located above the SAM-binding site of flavivirus MTase, a series of SAH analogs were rationally designed to bind into this site ([128,129]; Figure 2). Whilst the inhibitors were intended to target the DENV MTase, cross-reactivity to WNV MTase was observed [129]. Interestingly, the SAR appears to differ between the WNV and DENV MTases. WNV 2'- $O$ MTase appears to be more susceptible to inhibition than the DENV MTase. This suggests that it may be possible to generate DENV- or WNV-specific inhibitors via this flavivirus MTase-conserved hydrophobic cavity. The challenge with this approach is the need to overcome the zwitterion nature of the SAH molecules to allow the compounds to entry the cells. 
Using a GTP displacement fluorescent polarization assay with the YFV NS5 MTase domain, Geiss and colleagues performed a screen with a small library of 46,323 compounds. Six compounds were found to compete with GTP for bindng to both YFV and DENV MTase and also inhibited the DENV GTase activity [130]. The most potent compounds gave $\mathrm{IC}_{50}$ values of 5-8 $\mu \mathrm{M}$. A second screening exercise was conducted with 235,456 compounds against the DENV NS5 MTase domain and identified a family of compounds, with a thioxothiazolidin core, that bound to both DENV and YFV MTases and inhibited DENV GTase [131]. One particular analog, (E)-\{3-[5-(4-tert-butylbenzylidene)4-oxo-2-thioxo-1,3-thiazolidin-3-yl]propanoic acid\} (BG-323), possessed antiviral activity in DENV $\left(\mathrm{EC}_{50} 30.8 \mu \mathrm{M}\right)$ cell culture with low toxicity $\left(\mathrm{CC}_{50} 184 \mu \mathrm{M}\right)$. This compound also inhibited WNV (Kunjin) replication in cells, with up to 3 logs reduction in viral titre observed with $100 \mu \mathrm{M}$ of BG323. However, it is unclear if the cellular inhibition is directly due to effect on the viral MTase/GTase.

\subsection{2. $\operatorname{RdRp}$}

Viral polymerase inhibitors can be classified into two broad categories: Nucleoside/nucleotide analog inhibitors (NIs) and non-nucleoside inhibitors (NNIs). NIs, when converted to its corresponding triphosphate, can compete with natural NTP substrates and be integrated into the growing chain of viral genome, blocking subsequent NTP incorporation. Incorporation of the inhibitors into the growing RNA template can also cause further mis-incorporations, inducing mutational error catastrophe, which leads to non-viable viral RNA templates. NNIs usually bind to allosteric sites in the polymerase and either "lock" the enzyme into an inactive form or prevent conformational changes required to initiate and/or elongate a new RNA product.

NIs offer several advantages over NNIs. They target active sites, which are often conserved, and have a higher barrier of resistance [132]. Moreover, they often retain equivalent potency against different viral serotypes/genotypes and sometimes also work across related viruses. For example, a broad spectrum NI 5-aza-7-deazaguanosine was reported to inhibit DENV2, YFV, WNV, BVDV (bovine viral diarrhea virus), and Banzi virus at a single-digit micromolar concentration [133]. Cross-reactivity of nucleoside analogs to DENV1-4 and HCV has been reported by several groups [134-137]. Several NIs that are active against DENV also inhibit WNV. 7-deaza-2'-C-methyl-adenosine has $\mathrm{EC}_{50}$ of 4 and $15 \mu \mathrm{M}$ against WNV and DENV1, respectively [138]. Rather unfortunately, no information is available on in vivo efficacy and toxicity. Two NIs have been profiled in vivo. NITD-008 (beta-D-2'ethynyl-7-deaza-adenosine triphosphate) and NITD203 (3',5'- $O$-diisobutyryl-2'- $C$-acetylene-7-deaza7-carbamoyladenosine) have $\mathrm{EC}_{50} \mathrm{~s}$ of $<1 \mu \mathrm{M}$ for all four serotypes of DENV and $\mathrm{EC}_{50}$ of $\sim 5 \mu \mathrm{M}$ for WNV. Both NIs could not reach a satisfactory no-observable adverse-effect level (NOAEL) in 2-week in vivo toxicity studies in rats and dogs $[134,135]$. These findings underline the fact that toxicity of nucleoside analogs is unpredictable and is one of the challenges related to this class of inhibitors. Nevertheless, based on the experiences of other infectious diseases (such as herpesviruses, HIV-1, $\mathrm{HBV}$, and $\mathrm{HCV}$ ), NIs remain the most promising class of compounds to succeed in the clinics.

To date, there are no reported investigations of NNIs to WNV polymerase via diverse library screening or virtual screening. Unfortunately, researchers have not taken advantage of the relatively large amount of structural and biochemical information available on this enzyme [139-141]. One class of NNIs developed against DENV2 was not active against WNV polymerase [142]. This suggests that allosteric pockets may not be very well conserved in the two polymerases. Surface shape analysis of 
DENV3 and WNV RdRp crystal structures using in silico algorithms previously identified two cavities (A and B) common in the thumb domain of both proteins and additional three cavities unique to WNV ([143]; Figure 2). To determine if these cavities were potentially suitable for development of allosteric inhibitors, mutational analyses of conserved residues in these cavities was carried out in DENV2. Residues in cavity B, but not A, are critical for virus replication and mostly impaired NS5 polymerase activity in vitro [144]. Thus, cavity B could be used as a starting point for structure-based drug design or for virtual screening. The remaining three cavities in WNV RdRp, located in the thumb (cavity C and D) and in the finger subdomain (cavity E), have yet to be characterized. More recently, a co-crystal structure of DENV3 RdRp in complex with a small molecular weight inhibitor was reported [145]. It remains to be seen if this compound could be exploited as a starting point for designing inhibitors of WNV RdRp.

\section{Inhibitors of Host Targets}

"Hits" identified from the phenotypic cell-based screening could also inhibit host targets. The number of host factors required for a productive viral infection cycle is most probably higher than the number of virally encoded proteins (10 viral proteins in the case of WNV). Consequently, the probability of identifying inhibitors of host targets in cell-based assays would be greater than that for viral targets. The approach to target host proteins offers the advantage of a significantly higher barrier to spontaneous viral escape from inhibition, compared to direct antiviral agents, since viral mutations are less able to compensate for the loss of an essential host cofactor. Furthermore, since cellular replication of related viruses may involve similar host cell pathways, it may be possible to treat several viral indications with the same class of chemical compounds. For example, screening campaigns with DENV cell-based assays have uncovered compounds that also work on WNV (see below). The drawback of targeting host factors is the higher potential of undesirable drug-induced side effects, as these factors are often essential for cell survival or metabolism. For treatment of acute diseases, like dengue, this may be less of an issue compared to treatment of chronic diseases like HIV-1 or HCV [146]. For neurotropic flaviviruses like WNV, most symptomatic infections are associated with neuroinvasive disease and infection of neurons [147,148]. Thus, an additional consideration is that the compound must be able to cross the blood-brain barrier to be effective as a therapeutic agent.

\subsection{Inhibitors of Viral Replication and Translation}

Screening of the Novartis compound library with DENV induced cytopathic (CPE) assay led to the identification of a class of compounds with a benzomorphane core, which displayed a broad spectrum of anti-flavivirus activity [149]. It reduced the titer of DENV2, YFV, and WNV with $\mathrm{EC}_{50}$ of about 1, 4.9 , and $4.5 \mu \mathrm{M}$ respectively. The mode-of-action analysis indicated that the compounds inhibit protein translation in a viral RNA sequence-independent manner, but the exact protein that was affected by the compound was not identified. When tested in a dengue mouse viremia model, the most potent compound, NITD-451, reduced peak viremia by $40 \%$ at a low dose $(25 \mathrm{mg} / \mathrm{kg})$; but the compound resulted in adverse effects at higher doses. It would be interesting to determine the efficacy of this class of compounds in a WNV murine model and if the SAR established for DENV would track that for WNV. 
A screening exercise using luciferase expressing WNV subgenomic replicon discovered one class of potent inhibitors that target viral translation [150]. Compound AP30451 exhibited an excellent $\mathrm{EC}_{50}$ of $60 \mathrm{nM}$ and an SI of 533 in the WNV replicon assay; furthermore, the compound was active in neurons at a dose that did not cause significant cell toxicity. This compound also inhibited replication of DENV and YFV but not HCV replicons. Unfortunately, no further data is available on its further development.

Minocycline inhibited WNV replication and WNV-induced apoptosis in different human CNS-derived cell types with no evidence of cytotoxicity [151]. Minocycline acted through suppression of virus-induced activation of c-Jun $N$-terminal kinase (JNK) and its target c-jun.

Cyclophilins, a family of cellular peptidyl-prolyl isomerases (PPIases), play a role in flavivirus replication [152]. Cyclosporine (an 11-amino-acid cyclic peptide known to block the PPIase activity of Cyclophilin A) inhibits WNV and DENV replication in cell culture at nontoxic concentrations. Time-of-addition and transient replicon results indicated that Cs inhibits flavivirus at the step of viral RNA synthesis. Biochemical analysis showed that Cyclosporine directly blocks the interaction between Cyclophilin A and WNV NS5 protein [152]. The results suggest that host Cyclophilin A is a component of flavivirus replication complex. The inhibitors of Cyclophilin currently in clinical development for HCV could potentially be repurposed for WNV and other flaviviruses.

\subsection{Inhibitors of Host Pyrimidine or Purine Biosynthesis}

Viral replication relies on the host to supply nucleosides. Host enzymes involved in nucleoside biosynthesis are potential targets for antiviral development. Ribavirin and mycophenolic acid inhibit replication of flaviviruses in part by suppressing inosine monophosphate dehydrogenase (IMPDH) enzyme activity, leading to depletion of the intracellular GTP pool [153-155]. Interestingly, the antiviral effects of both these compounds are augmented by induction of interferon-stimulated genes (ISGs) [156,157]. In addition, 6-azauridine (acts by blocking the conversion of orotic acid into UMP) has single digit micormolar inhibition against WNV. The utility of the latter two compounds is hampered by the cytostatic effects [158].

Recently, two classes of compounds were found to inhibit flavivirus replication by suppressing host pyrimidine biosynthesis. Firstly, NITD-982, a compound with an isoxazole-pyrazole core was identified from a CPE (cytopathic effect)-based HTS campaign [159]. It displayed nanomolar potency against four different RNA virus families, including Flaviviridae, Paramyxoviridae, Orthomyxoviridae, and Retroviridae. The compound was shown to inhibit the enzymatic activity of recombinant DHODH and to directly bind the DHODH protein. Inhibition of DHODH activity by NITD-982 resulted in depletion of intracellular pyrimidine pools, leading to the suppression of viral RNA synthesis. The second class of compounds, brequinar, also inhibited DHODH and could inhibit flaviviruses (DENV, WNV, YFV, and Powassan virus), alphavirus (Western equine encephalitis virus), and rhabdovirus (VSV) [160]. Supplementing the culture medium with pyrimidines reversed antiviral activities of both classes of compounds. Thus, the in vitro efficacy did not translate into in vivo efficacy and could be attributed to the uridine uptake from diets that replenish and maintain a high concentration of pyrimidine in plasma, which counteracted the compound-mediated inhibition of viral replication. 


\subsection{Inhibitors to Virus Assembly and Maturation}

Celgosivir (butyl-castanospermine), is an oral prodrug of the natural product castanospermine, inhibits alpha-glucosidase I, an enzyme that plays a critical role in viral maturation by initiating the processing of the N-linked oligosaccharides of viral E and NS1 glycoproteins. It was tested in a phase II clinical trials in combination with peglated IFN and ribavirin for treatment of HCV infection; addition of celgosivir did not show any benefit when compared with the standard IFN/ribavirin regime [161]. Several studies have indicated that castanospermine and celgosivir also inhibits DENV replication in cell cultures and mouse models [162-164]. Celgosivir has been recently tested in dengue patients; the efficacy has not been published. Notably, celgosivir did not show any protective effect on WNV-infected cells or mice [162]. Imino sugars, such as N-butyl-deoxynojirimycin (DNJ) and Nnonyl-deoxynojirimycin (NNDNJ), inhibit both alpha-glucosidase I and II. Derivatives of DNJ, such as N-pentyl-(1-hydroxycyclohexyl)-DNJ (OSL-95II), PBDNJ0801, PBDNJ0803, and PBDNJ0804, had micromolar antiviral activity against BVDV, WNV, DENV, and HBV without observable cytotoxic effects [165,166].

Several host proteins have been reported to be involved in virus assembly and maturation. These may potentially be explored as host target to inhibit virus particle formation and dissemination. The host nucleolar helicase DDX56/NOH61 interacts with WNV capsid protein and is essential for assembly of infectious WNV virions [167,168]. The src family kinase (SFK), c-Yes, has also been implicated to play a role in transit of WNV particles through the secretory pathway. Treatment of WNV-infected cells with the SFK inhibitor PP2 reduced the E protein glycosidation, leading to accumulation of virions in the ER compartment [169]. Recent advances in development of peptidomimetic furin inhibitors yielded in compounds with picomolar activity and enhanced stability in cell culture. They inhibited the hemagglutinin cleavage and viral propagation of a highly pathogenic avian H7N1 influenza virus strain [170]. Inhibitors of furin or furin-like proprotein convertases could represent promising antiviral drug candidates for infectious diseases such as WNV.

\section{Discussion and Perspectives}

Compared with HCV or DENV, the effort for WNV drug discovery is much lower. This may be due to the perception that there is not an urgent need for antivirals against this disease. Most human infections with WNV are asymptomatic, with about $20 \%$ of individuals developing flulike symptoms with high fever. Only about $1 \%$ of cases develop severe neuroinvasive disease (encephalitis, meningitis or flaccid paralysis). Infection with WNV is mostly transient and leaves a life-long immunity although persistent infections have been demonstrated occasionally. With time, it is expected that WNV seroprevalence will increase both in the human and bird populations, resulting in increasing immunity and a reduction in outbreaks [171]. Nevertheless, given the mutability of the virus, in particular for enhanced neuroinvasiveness, it is possible that new waves of WNV outbreak may take place from newly emerging virulent isolates. Under these circumstances, antiviral remains the best hope for intervention. Due to the homology among different flaviviruses, antivirals developed for DENV may potentially be useful for WNV and other flaviviruses. In both laboratory and clinical settings, the genetic barrier to drug resistance varies depending on the classes of DAAs. The phenotypes of compound-resistant mutant viruses cultured under laboratory settings also depends on the selection protocol used, and do 
not necessarily correlate with mutations observed in drug-treated patients [132,172]. In general, nucleoside analogues have a much higher barrier to resistance than protease and NIs. Any treatment regime envisaged for WNV disease would benefit with the incorporation of a NI.

\section{Acknowledgments}

We thank Novartis internal and external colleagues and collaborators for useful discussions.

\section{Conflicts of Interest}

The authors declare no conflict of interest.

\section{References}

1. Shi, P.Y.; Brinton, M.A.; Veal, J.M.; Zhong, Y.Y.; Wilson, W. D. Evidence for the existence of a pseudoknot structure at the 3' terminus of the flavivirus genomic RNA. Biochemistry 1996, 35, 4222-4230.

2. Khromykh, A.A.; Meka, H.; Guyatt, K.J.; Westaway, E.G. Essential role of cyclization sequences in flavivirus RNA replication. J. Virol. 2001, 75, 6719-6728.

3. Friebe, P.; Harris, E. Interplay of RNA elements in the dengue virus 5'and 3' ends required for viral RNA replication. J. Virol. 2010, 84, 6103-6118.

4. Lindenbach, B.D.; Thiel, H.J.; Rice, C.M. Flaviviridae: The Virus and Their Replication. In Fields Virology, 5th ed.; Knipe, D.M., Howley, P.M., Eds.; Lippincott-Raven: Philadelphia, PA, USA, 2007; Volume 1, p. 1101.

5. Westaway, E.G.; Mackenzie, J.M.; Khromykh, A.A. Replication and gene function in Kunjin virus. Curr. Top. Microbiol. Immunol. 2002, 267, 323-351.

6. Melian, E.B.; Hinzman, E.; Nagasaki, T.; Firth, A.E.; Wills, N.M.; Nouwens, A.S.; Blitvich, B.J.; Leung, J.; Funk, A.; Atkins, J.F.; et al. NS1' of flaviviruses in the Japanese encephalitis virus serogroup is a product of ribosomal frameshifting and plays a role in viral neuroinvasiveness. J. Virol. 2010, 84, 1641-1647.

7. Roosendaal, J.; Westaway, E.G.; Khromykh, A.; Mackenzie, J.M. Regulated cleavages at the West Nile virus NS4A-2K-NS4B junctions play a major role in rearranging cytoplasmic membranes and Golgi trafficking of the NS4A protein. J. Virol. 2006, 80, 4623-4632.

8. Miller, S.; Kastner, S.; Krijnse-Locker, J.; Buhler, S.; Bartenschlager, R. The non-structural protein $4 \mathrm{~A}$ of dengue virus is an integral membrane protein inducing membrane alterations in a 2K-regulated manner. J. Biol. Chem. 2007, 282, 8873-8882.

9. Miller, S.; Sparacio, S.; Bartenschlager, R. Subcellular localization and membrane topology of the dengue virus type 2 non-structural protein 4B. J. Biol. Chem. 2006, 281, 8854-8863.

10. Colpitts, T.M.; Conway, M.J.; Montgomery, R.R.; Fikrig, E. West Nile Virus: Biology, transmission, and human infection. Clin. Microbiol. Rev. 2012, 25, 635-648.

11. Gao, M.; Nettles, R.E.; Belema, M.; Snyder, L.B.; Nguyen, V.N.; Fridell, R.A.; Serrano-Wu, M.H.; Langley, D.R.; Sun, J.H.; O’Boyle, D.R., II; et al. Chemical genetics strategy identifies an HCV NS5A inhibitor with a potent clinical effect. Nature 2010, 465, 96-100. 
12. Mukhopadhyay, S.; Kuhn, R.J.; Rossmann, M.G. A structural perspective of the flavivirus life cycle. Nat. Rev. Microbiol. 2005, 3, 13-22.

13. Perera, R.; Kuhn, R.J. Structural proteomics of dengue virus. Curr. Opin. Microbiol. 2008, 11, 369-377.

14. Perera, R.; Khaliq, M.; Kuhn, R.J. Closing the door on Flaviviruses: Entry as a target for antiviral drug design. Antivir. Res. 2008, 80, 11-22.

15. Modis, Y.; Ogata, S.; Clements, D.; Harrison, S.C. A ligand-binding pocket in the dengue virus envelope glycoprotein. Proc. Natl. Acad. Sci. USA 2003, 100, 6986-6991.

16. Zhou, Z.; Khaliq, M.; Suk, J.E.; Patkar, C.; Li, L.; Kuhn, R.J.; Post, C.B. Antiviral compounds discovered by virtual screening of small-molecule libraries against dengue virus $\mathrm{E}$ protein. ACS Chem. Biol. 2008, 3, 765-775.

17. Poh, M.K.; Yip, A.; Zhang, S.; Priestle, J.P.; Ma, N.L.; Smit, J.M.; Wilschut, J.; Shi, P.Y.; Wenk, M.R.; Schul, W.A. small molecule fusion inhibitor of dengue virus. Antivir. Res. 2009, 84, 260-266.

18. Yennamalli, R.; Subbarao, N.; Kampmann, T.; McGeary, R.P.; Young, P.R.; Kobe, B. Identification of novel target sites and an inhibitor of the dengue virus E protein. J. Comput. Aided Mol. Des. 2009, 23, 333-341.

19. Wang, Q.Y.; Patel, S.J.; Vangrevelinghe, E.; Xu, H.Y.; Rao, R.; Jaber, D.; Schul, W.; Gu, F.; Heudi, O.; Ma, N.L.; et al. A small-molecule dengue virus entry inhibitor. Antimicrob. Agents Chemother. 2009, 53, 1823-1831.

20. Kampmann, T.; Yennamalli, R.; Campbell, P.; Stoermer, M.J.; Fairlie, D.P.; Kobe, B.; Young, P.R. In silico screening of small molecule libraries using the dengue virus envelope $\mathrm{E}$ protein has identified compounds with antiviral activity against multiple Flaviviruses. Antivir. Res. 2009, 84, 234-241.

21. Li, Z.; Khaliq, M.; Zhou, Z.; Post, C.B.; Kuhn, R.J.; Cushman, M. Design, synthesis, and biological evaluation of antiviral agents targeting flavivirus envelope proteins. J. Med. Chem. 2008, 51, 4660-4671.

22. Mayhoub, A.S.; Khaliqm, M.; Botting, C.; Li, Z.; Kuhn, R.J.; Cushman, M. An investigation of phenylthiazole anti-flaviviral agents. Bioorg. Med. Chem. 2011, 19, 3845-3854.

23. Mayhoub, A.S.; Khaliq, M.; Kuhn, R.J.; Cushman, M. Design, synthesis, and biological evaluation of thiazoles targeting flavivirus envelope proteins. J. Med. Chem. 2011, 54, 1704-1714.

24. Chu, J.J.; Rajamanonmani, R.; Li, J.; Bhuvanakantham, R.; Lescar, J.; Ng, M.L. Inhibition of West Nile virus entry by using a recombinant domain III from the envelope glycoprotein.

J. Gen. Virol. 2005, 86, 405-412.

25. Hrobowski, Y.M.; Garry, R.F.; Michael, S.F. Peptide inhibitors of dengue virus and West Nile virus infectivity. Virol. J. 2005, 2, doi:10.1186/1743-422X-2-49.

26. Diamond, M.S.; Pierson, T.C.; Roehrig, J.T. Molecular Virology and Control of Flaviviruses; Shi P., Ed.; Caister Academic Press: Norfolk, UK, 2012; Chapter 11, p. 231.

27. Haley, M.; Retter, A.S.; Fowler, D.; Gea-Banacloche, J.; O’Grady, N.P. The role for intravenous immunoglobulin in the treatment of West Nile virus encephalitis. Clin. Infect. Dis. 2003, 37, e88-e90. 
28. Hamdan, A.; Green, P.; Mendelson, E.; Kramer, M.R.; Pitlik, S.; Weinberger, M. Possible benefit of intravenous immunoglobulin therapy in a lung transplant recipient with West Nile virus encephalitis. Transpl. Infect. Dis. 2002, 4, 160-162.

29. Saquib, R.; Randall, H.; Chandrakantan, A.; Spak, C.W.; Barri, Y.M. West Nile virus encephalitis in a renal transplant recipient: the role of intravenous immunoglobulin. Am. J. Kidney Dis. 2008, 52 , e19-e21.

30. Shimoni, Z.; Niven, M.J.; Pitlick, S.; Bulvik, S. Treatment of West Nile virus encephalitis with intravenous immunoglobulin. Emerg. Infect. Dis. 2001, 7, 759.

31. Oliphant, T.; Engle, M.; Nybakken, G.E.; Doane, C.; Johnson, S.; Huang, L.; Gorlatov, S.; Mehlhop, E.; Marri, A.; Chung, K.M.; et al. Development of a humanized monoclonal antibody with therapeutic potential against West Nile virus. Nat. Med. 2005, 11, 522-530.

32. Morrey, J.D.; Siddharthan, V.; Olsen, A.L.; Roper, G.Y.; Wang, H.; Baldwin, T.J.; Koenig, S.; Johnson, S.; Nordstrom, J.L.; Diamond, M.S. Humanized monoclonal antibody against West Nile virus envelope protein administered after neuronal infection protects against lethal encephalitis in hamsters. J. Infect. Dis. 2006, 194, 1300-1308.

33. Morrey, J.D.; Siddharthan, V.; Olsen, A.L.; Wang, H.; Julander, J.G.; Hall, J.O.; Li, H.; Nordstrom, J.L.; Koenig, S.; Johnson, S.; et al. Defining limits of treatment with humanized neutralizing monoclonal antibody for West Nile virus neurological infection in a hamster model. Antimicrob. Agents Chemother. 2007, 51, 2396-2402.

34. Gorbalenya, A.E.; Donchenko, A.P.; Koonin, E.V.; Blinov, V.M. N-terminal domains of putative helicases of flavi- and pestiviruses may be serine proteases. Nucleic Acids Res. 1989, 17, 3889-3897.

35. Wengler, G.; Wengler, G. The carboxy-terminal part of the NS 3 protein of the West Nile flavivirus can be isolated as a soluble protein after proteolytic cleavage and represents an RNA-stimulated NTPase. Virology 1991, 184, 707-715.

36. Wengler, G.; Czaya, G.; Färber, P.M.; Hegemann, J.H. In vitro synthesis of West Nile virus proteins indicates that the amino-terminal segment of the NS3 protein contains the active centre of the protease which cleaves the viral polyprotein after multiple basic amino acids. J. Gen. Virol. 1991, 72, 851-858.

37. Luo, D.; Xu, T.; Hunke, C.; Gruber, G.; Vasudevan, S.G.; Lescar, J. Crystal structure of the NS3 protease-helicase from dengue virus. J. Virol. 2008, 82, 173-183.

38. Assenberg, R.; Mastrangelo, E.; Walter, T.S.; Verma, A.; Milani, M.; Owens, R.J.; Stuart, D.I.; Grimes, J.M.; Mancini, E.J. Crystal structure of a novel conformational state of the flavivirus NS3 protein: Implications for polyprotein processing and viral replication. J. Virol. 2009, 83, 12895-12906.

39. Erbel, P.; Schiering, N.; D’Arcy, A.; Renatus, M.; Kroemer, M.; Lim, S.P.; Yin, Z.; Keller, T.H.; Vasudevan, S.G.; Hommel, U. Structural basis for the activation of flaviviral NS3 proteases from dengue and West Nile virus. Nat. Struct. Mol. Biol. 2006, 13, 372-373.

40. Mastrangelo, E.; Milani, M.; Bollati, M.; Selisko, B.; Peyrane, F.; Pandini, V.; Sorrentino, G.; Canard, B.; Konarev, P.V.; Svergun, D.I.; et al. Crystal structure and activity of Kunjin virus NS3 helicase; protease and helicase domain assembly in the full length NS3 protein. J. Mol. Biol. 2007, 372, 444-455. 
41. Robin, G.; Chappell, K.; Stoermer, M.J.; Hu, S.H.; Young, P.R.; Fairlie, D.P.; Martin, J.L. Structure of West Nile virus NS3 protease: Ligand stabilization of the catalytic conformation. J. Mol. Biol. 2009, 385, 1568-1577.

42. Aleshin, A.E.; Shiryaev, S.A.; Strongin, A.Y.; Liddington, R.C. Structural evidence for regulation and specificity of flaviviral proteases and evolution of the Flaviviridae fold. Protein Sci. 2007, 16, 795-806.

43. Hammamy, M.Z.; Haase, C.; Hammami, M.; Hilgenfeld, R.; Steinmetzer, T. Development and characterization of new peptidomimetic inhibitors of the West Nile virus NS2B-NS3 protease. ChemMedChem 2013, 8, 231-241.

44. Chernov, A.V.; Shiryaev, S.A.; Aleshin, A.E.; Ratnikov, B.I.; Smith, J.W.; Liddington, R.C.; Strongin, A.Y. The two-component NS2B-NS3 proteinase represses DNA unwinding activity of the West Nile virus NS3 helicase. J. Biol. Chem. 2008, 283, 17270-17278.

45. Shiryaev, S.A.; Chernov, A.V.; Aleshin, A.E.; Shiryaev, T.N.; Strongin, A.Y. NS4A regulates the ATPase activity of the NS3 helicase: A novel cofactor role of the non-structural protein NS4A from West Nile virus. J. Gen. Virol. 2009, 90, 2081-2085.

46. Borowski, P.; Niebuhr, A.; Mueller, O.; Bretner, M.; Felczak, K.; Kulikowski, T.; Schmitz, H. Purification and characterization of West Nile virus nucleoside triphosphatase (NTPase)/helicase: Evidence for dissociation of the NTPase and helicase activities of the enzyme. J. Virol. 2001, 75, 3220-3229.

47. Westaway, E.G.; Mackenzie, J.M.; Kenney, M.T.; Jones, M.K.; Khromykh, A.A. Ultrastructure of Kunjin virus-infected cells: colocalization of NS1 and NS3 with double-stranded RNA, and of NS2B with NS3, in virus-induced membrane structures. J. Virol. 1997, 71, 6650-6661.

48. Bazan, J.F.; Fletterick, R.J. Detection of a trypsin-like serine protease domain in flaviviruses and pestiviruses. Virology 1989, 171, 637-639.

49. Falgout, B.; Pethel, M.; Zhang, Y.M.; Lai, C.J. Both nonstructural proteins NS2B and NS3 are required for the proteolytic processing of dengue virus nonstructural proteins. J. Virol. 1991, 65, 2467-2475.

50. McMinn, P.C. The molecular basis of virulence of the encephalitogenic flaviviruses. J. Gen. Virol. 1997, 78, 2711-2722.

51. Chiou, S.S.; Chen, W.J. Mutations in the NS3 gene and 3'-NCR of Japanese encephalitis virus isolated from an unconventional ecosystem and implications for natural attenuation of the virus. Virology 2001, 289, 129-136.

52. Ramanathan, M.P.; Chambers, J.A.; Pankhong, P.; Chattergoon, M.; Attatippaholkun, W.; Dang, K.; Shah, N.; Weiner, D.B. Host cell killing by the West Nile Virus NS2B-NS3 proteolytic complex: NS3 alone is sufficient to recruit caspase-8-based apoptotic pathway. Virology 2006, 345, 56-72.

53. De Clercq, E. Anti-HIV drugs: 25 compounds approved within 25 years after the discovery of HIV. Int. J. Antimicrob. Agents 2009, 33, 307-320.

54. Wyles, D.L. Antiviral resistance and the future landscape of hepatitis C virus infection therapy. J. Infect. Dis. 2013, 207, S33-S39.

55. Halfon, P.; Locarnini, S. Hepatitis C virus resistance to protease inhibitors. J. Hepatol. 2011, 55, 192-206. 
56. Paolucci, S.; Fiorina, L.; Piralla, A.; Gulminetti, R.; Novati, S.; Barbarini, G.; Sacchi, P.; Gatti, M.; Dossena, L.; Baldanti, F. Naturally occurring mutations to HCV protease inhibitors in treatment-naïve patients. Virol. J. 2012, 9, doi:10.1186/1743-422X-9-245.

57. Cento, V.; Mirabelli, C.; Salpini, R.; Dimonte, S.; Artese, A.; Costa, G.; Mercurio, F.; Svicher, V.; Parrotta, L.; Bertoli, A.; et al. HCV genotypes are differently prone to the development of resistance to linear and macrocyclic protease inhibitors. PLoS One 2012, 7, e39652.

58. Murray, K.; Walker, C.; Herrington, E.; Lewis, J.A.; McCormick, J.; Beasley, D.W.; Tesh, R.B.; Fisher-Hoch S. Persistent infection with West Nile virus years after initial infection. J. Infect. Dis. 2010, 201, 2-4.

59. Sejvar, J.J. The long-term outcomes of human West Nile virus infection. Clin. Infect. Dis. 2007, $44,1617-1624$.

60. Cook, R.L.; Xu, X.; Yablonsky, E.J.; Sakata, N.; Tripp, J.H.; Hess, R.; Piazza, P.; Rinaldo, C.R. Demographic and clinical factors associated with persistent symptoms after West Nile virus infection. Am. J. Trop. Med. Hyg. 2010, 83, 1133-1136.

61. Nolan, M.S.; Podoll, A.S.; Hause, A.M.; Akers, K.M.; Finkel, K.W.; Murray, K.O. Prevalence of chronic kidney disease and progression of disease over time among patients enrolled in the Houston West Nile virus cohort. PLoS One 2012, 7, e40374.

62. Chappell, K.J.; Stoermer, M.J.; Fairlie, D.P.; Young, P.R. West Nile Virus NS2B/NS3 protease as an antiviral target. Curr. Med. Chem. 2008, 15, 2771-2784.

63. Bollati, M.; Alvarez, K.; Assenberg, R.; Baronti, C.; Canard, B.; Cook, S.; Coutard, B.; Decroly, E.; de Lamballerie, X.; Gould, E.A.; et al. Structure and functionality in flavivirus NS-proteins: perspectives for drug design. Antivir. Res. 2010, 87, 125-148.

64. Shiryaev, S.A.; Strongin, A.Y. Structural and functional parameters of the flaviviral protease: A promising antiviral drug target. Future Virol. 2010, 5, 593-606.

65. Steuber, H.; Hilgenfeld, R. Recent advances in targeting viral proteases for the discovery of novel antivirals. Curr. Top. Med. Chem. 2010, 10, 323-345.

66. Noble, C.G.; She, C.C.; Chao, A.T.; Shi, P.Y. Ligand-bound structures of the dengue virus protease reveal the active conformation. J. Virol. 2012, 86, 438-446.

67. Su, X.C.; Ozawa, K.; Yagi, H.; Lim, S.P.; Wen, D.; Ekonomiuk, D.; Huang, D.; Keller, T.H.; Sonntag, S.; Caflisch, A.; et al. NMR study of complexes between low molecular mass inhibitors and the West Nile virus NS2B-NS3 protease. FEBS J. 2009, 276, 4244-4255.

68. Su, X.C.; Ozawa, K.; Qi, R.; Vasudevan, S.G.; Lim, S.P.; Otting, G. NMR analysis of the dynamic exchange of the NS2B cofactor between open and closed conformations of the West Nile virus NS2B-NS3 protease. PLoS Negl. Trop. Dis. 2009, 3, e561.

69. Kim, Y.M.; Gayen, S.; Kang, C.; Joy, J.; Huang, Q.; Chen, A.S.; Wee, J.L.; Ang, M.J.; Lim, H.A.; Hung, A.W.; et al. NMR analysis of a novel enzymatically active unlinked dengue NS2B-NS3 protease complex. J. Biol. Chem. 2013, 288, 12891-12900.

70. Knox, J.E.; Ma, N.L.; Yin, Z.; Patel, S.J.; Wang, W.L.; Chan, W.L.; Ranga Rao, K.R.; Wang, G.; Ngew, X.; Patel, V.; et al. Peptide inhibitors of West Nile NS3 protease: SAR study of tetrapeptide aldehyde inhibitors. J. Med. Chem. 2006, 49, 6585-6890. 
71. Stoermer, M.J.; Chappell, K.J.; Liebscher, S.; Jensen, C.M.; Gan, C.H.; Gupta, P.K.; Xu, W.J.; Young, P.R.; Fairlie, D.P. Potent cationic inhibitors of West Nile virus NS2B/NS3 protease with serum stability, cell permeability and antiviral activity. J. Med. Chem. 2008, 51, 5714-5721.

72. Schüller, A.; Yin, Z.; Brian Chia C.S.; Doan, D.N.; Kim, H.K.; Shang, L.; Loh, T.P.; Hill, J.; Vasudevan, S.G. Tripeptide inhibitors of dengue and West Nile virus NS2B-NS3 protease. Antivir. Res. 2011, 92, 96-101.

73. Mueller, N.H.; Yon, C.; Ganesh, V.K.; Padmanabhan, R. Characterization of the West Nile virus protease substrate specificity and inhibitors. Int. J. Biochem. Cell Biol. 2007, 39, 606-614.

74. Cregar-Hernandez, L.; Jiao, G.S.; Johnson, A.T.; Lehrer, A.T.; Wong, T.A.; Margosiak, S.A. Small molecule pan-dengue and West Nile virus NS3 protease inhibitors. Antivir. Chem. Chemother. 2011, 21, 209-217.

75. Shiryaev, S.A.; Ratnikov, B.I.; Chekanov, A.V.; Sikora, S.; Rozanov, D.V.; Godzik, A.; Wang, J.; Smith, J.W.; Huang, Z.; Lindberg, I.; et al. Cleavage targets and the D-arginine-based inhibitors of the West Nile virus NS3 processing proteinase. Biochem. J. 2006, 393, 503-511.

76. Kang, C.; Gayen, S.; Wang, W.; Severin, R.; Chen, A.S.; Lim, H.A.; Chia, C.S.; Schüller, A.; Doan, D.N.; Poulsen, A.; et al. Exploring the binding of peptidic West Nile virus NS2B-NS3 protease inhibitors by NMR. Antivir. Res. 2013, 97, 137-144.

77. Lim, H.A.; Joy, J.; Hill, J.; San Brian Chia, C. Novel agmatine and agmatine-like peptidomimetic inhibitors of the West Nile virus NS2B/NS3 serine protease. Eur. J. Med. Chem. 2011, 46, 3130-3134.

78. Lim, H.A.; Ang, M.J.; Joy, J.; Poulsen, A.; Wu, W.; Ching, S.C.; Hill, J.; Chia, C.S. Novel agmatine dipeptide inhibitors against the West Nile virus NS2B/NS3 protease: A P3 and N-cap optimization study. Eur. J. Med. Chem. 2013, 62, 199-205.

79. Nitsche, C.; Steuer, C.; Klein, C.D. Arylcyanoacrylamides as inhibitors of the Dengue and West Nile virus proteases. Bioorg. Med. Chem. 2011, 19, 7318-7337.

80. Eisert, W.G.; Hauel, N.; Stangier, J.; Wienen, W.; Clemens, A.; van Ryn, J. Dabigatran: An oral novel potent reversible nonpeptide inhibitor of thrombin. Arterioscler. Thromb. Vasc. Biol. 2010, 30, 1885-1889.

81. Perzborn, E.; Roehrig, S.; Straub, A.; Kubitza, D.; Misselwitz, F. The discovery and development of rivaroxaban, an oral, direct factor Xa inhibitor. Nat. Rev. Drug Discov. 2011, 10, 61-75.

82. Mueller, N.H.; Pattabiraman, N.; Ansarah-Sobrinho, C.; Viswanathan, P.; Pierson, T.C.; Padmanabhan, R. Identification and biochemical characterization of small-molecule inhibitors of west nile virus serine protease by a high-throughput screen. Antimicrob. Agents Chemother. 2008, 52, 3385-3393.

83. Ezgimen, M.; Lai, H.; Mueller, N.H.; Lee, K.; Cuny, G.; Ostrov, D.A.; Padmanabhan, R. Characterization of the 8-hydroxyquinoline scaffold for inhibitors of West Nile virus serine protease. Antivir. Res. 2012, 94, 18-24.

84. Dou, D.; Viwanathan, P.; Li, Y.; He, G.; Alliston, K.R.; Lushington, G.H.; Brown-Clay, J.D.; Padmanabhan, R.; Groutas, W.C. Design, synthesis, and in vitro evaluation of potential West Nile virus protease inhibitors based on the 1-oxo-1,2,3,4-tetrahydroisoquinoline and 1-oxo-1,2dihydroisoquinoline scaffolds. J. Comb Chem. 2010, 12, 836-843. 
85. Jia, F.; Zou, G.; Fan, J.; Yuan, Z. Identification of palmatine as an inhibitor of West Nile virus. Arch. Virol. 2010, 155, 1325-1329.

86. Ekonomiuk, D.; Su, X.C.; Ozawa, K.; Bodenreider, C.; Lim, S.P.; Yin, Z.; Keller, T.H.; Beer, D.; Patel, V.; Otting, G.; et al. Discovery of a non-peptidic inhibitor of west nile virus NS3 protease by high-throughput docking. PLoS Negl. Trop. Dis. 2009, 3, e356.

87. Ekonomiuk, D.; Su, X.C.; Ozawa, K.; Bodenreider, C.; Lim, S.P.; Otting, G.; Huang, D.; Caflisch, A. Flaviviral protease inhibitors identified by fragment-based library docking into a structure generated by molecular dynamics. J. Med Chem. 2009, 52, 4860-4868.

88. Johnston, P.A.; Phillips, J.; Shun, T.Y.; Shinde, S.; Lazo, J.S.; Huryn, D.M.; Myers, M.C.; Ratnikov, B.; Smith, J.W.; et al. HTS identifies novel and specific uncompetitive inhibitors of the two-component NS2B-NS3 proteinase of West Nile virus. Assay. Drug Dev. Technol. 2007, 5, 737-750.

89. Sidique, S.; Shiryaev, S.A.; Ratnikov, B.I.; Herath, A.; Su, Y.; Strongin, A.Y.; Cosford, N.D. Structure-activity relationship and improved hydrolytic stability of pyrazole derivatives that are allosteric inhibitors of West Nile Virus NS2B-NS3 proteinase. Bioorg. Med. Chem. Lett. 2009, 19, 5773-5777.

90. Samanta, S.; Lim, T.L.; Lam, Y. Synthesis and in vitro evaluation of West Nile virus protease inhibitors based on the 2-\{6-[2-(5-phenyl-4H- $\{1,2,4]$ triazol-3-ylsulfanyl)acetylamino] benzothiazol-2-ylsulfanyl \}acetamide scaffold. ChemMedChem 2013, 8, 994-1001.

91. Gao, Y.; Samanta, S.; Cui, T.; Lam, Y. Synthesis and in vitro evaluation of West Nile Virus Protease inhibitors based on the 1,3,4,5-Tetrasubstituted 1H-Pyrrol-2(5H)-one Scaffold. ChemMedChem 2013, in press.

92. Samanta, S.; Cui, T.; Lam, Y. Discovery, synthesis, and in vitro evaluation of West Nile virus protease inhibitors based on the 9,10-dihydro-3H,4aH-1,3,9,10a-tetraazaphenanthren-4-one scaffold. ChemMedChem 2012, 7, 1210-1216.

93. Tomlinson, S.M.; Watowich, S.J. Use of parallel validation high-throughput screens to reduce false positives and identify novel dengue NS2B-NS3 protease inhibitors. Antivir. Res. 2012, 93, 245-252.

94. Shiryaev, S.A.; Cheltsov, A.V.; Gawlik, K.; Ratnikov, B.I.; Strongin, AY. Virtual ligand screening of the National Cancer Institute (NCI) compound library leads to the allosteric inhibitory scaffolds of the West Nile Virus NS3 proteinase. Assay Drug Dev. Technol. 2011, 9 , 69-78.

95. Brault, A.C.; Huang, C.Y.; Langevin, S.A.; Kinney, R.M.; Bowen, R.A.; Ramey, W.N.; Panella, N.A.; Holmes, E.C.; Powers, A.M.; Miller, B.R. A single positively selected West Nile viral mutation confers increased virogenesis in American crows. Nat. Genet. 2007, 39, 1162-1166.

96. Mertens, E.; Kajaste-Rudnitski, A.; Torres, S.; Funk, A.; Frenkiel, M.P.; Iteman, I.; Khromykh, A.A.; Desprès, P. Viral determinants in the NS3 helicase and $2 \mathrm{~K}$ peptide that promote West Nile virus resistance to antiviral action of 2',5'-oligoadenylate synthetase $1 \mathrm{~b}$. Virology 2010, 399, 176-185.

97. Mastrangelo, E.; Pezzullo, M.; de Burghgraeve, T.; Kaptein, S.; Pastorino, B.; Dallmeier, K.; de Lamballerie, X.; Neyts, J.; Hanson, A.M.; Frick, D.N.; et al. Ivermectin is a potent inhibitor of 
flavivirus replication specifically targeting NS3 helicase activity: New prospects for an old drug. J. Antimicrob. Chemother. 2012, 67, 1884-1894.

98. Kline, K.; McCarthy, J.S.; Pearson, M.; Loukas, A.; Hotez, P.J. Neglected tropical diseases of Oceania: Review of their prevalence, distribution, and opportunities for control. PLoS Negl. Trop. Dis. 2013, 7, e1755.

99. Wagstaff, K.M.; Sivakumaran, H.; Heaton, S.M.; Harrich, D.; Jans, D.A. Ivermectin is a specific inhibitor of importin $\alpha / \beta$-mediated nuclear import able to inhibit replication of HIV-1 and dengue virus. Biochem. J. 2012, 443, 851-856.

100. Tay, M.Y.; Fraser, J.E.; Chan, W.K.; Moreland, N.J.; Rathore, A.P.; Wang, C.; Vasudevan, S.G.; Jans, D.A. Nuclear localization of dengue virus (DENV) 1-4 non-structural protein 5; protection against all 4 DENV serotypes by the inhibitor Ivermectin. Antivir. Res. 2013, 99, 301-306.

101. Borowski, P.; Heising, M.V.; Miranda, I.B.; Liao, C.L.; Choe, J.; Baier, A. Viral NS3 helicase activity is inhibited by peptides reproducing the Arg-rich conserved motif of the enzyme (motif VI). Biochem. Pharmacol. 2008, 76, 28-38.

102. Bretner, M.; Baier, A.; Kopańska, K.; Najda, A.; Schoof, A.; Reinholz, M.; Lipniacki, A.; Piasek, A.; Kulikowski, T.; Borowski, P. Synthesis and biological activity of 1H-benzotriazole and 1H-benzimidazole analogues-Inhibitors of the NTpase/helicase of HCV and of some related Flaviviridae. Antivir. Chem. Chemother. 2005, 16, 315-326.

103. Ujjinamatada, R.K.; Baier, A.; Borowski, P.; Hosmane, R.S. An analogue of AICAR with dual inhibitory activity against WNV and HCV NTPase/helicase: Synthesis and in vitro screening of 4-carbamoyl-5-(4,6-diamino-2,5-dihydro-1,3,5-triazin-2-yl)imidazole-1-beta-D-ribofuranoside.

Bioorg. Med. Chem. Lett. 2007, 17, 2285-2288.

104. Borowski, P.; Deinert, J.; Schalinski, S.; Bretner, M.; Ginalski, K.; Kulikowski, T.; Shugar, D. Halogenated benzimidazoles and benzotriazoles as inhibitors of the NTPase/helicase activities of hepatitis C and related viruses. Eur. J. Biochem. 2003, 270, 1645-1653.

105. Bretner, M.; Schalinski, S.; Haag, A.; Lang, M.; Schmitz, H.; Baier, A.; Behrens, S.E.; Kulikowski, T.; Borowski, P. Synthesis and evaluation of ATP-binding site directed potential inhibitors of nucleoside triphosphatases/helicases and polymerases of hepatitis $\mathrm{C}$ and other selected Flaviviridae viruses. Antivir. Chem. Chemother. 2004, 15, 35-42.

106. Zhang, N.; Chen, H.M.; Koch, V.; Schmitz, H.; Minczuk, M.; Stepien, P.; Fattom, A.I.; Naso, R.B.; Kalicharran, K.; Borowski, P.; et al. Potent inhibition of NTPase/helicase of the West Nile Virus by ring-expanded ("fat") nucleoside analogues. J. Med Chem. 2003, 46, 4776-4789.

107. Zhang, N.; Chen, H.M.; Koch, V.; Schmitz, H.; Liao, C.L.; Bretner, M.; Bhadti, V.S.; Fattom, A.I.; Naso, R.B.; Hosmane, R.S.; et al. Ring-expanded ("fat") nucleoside and nucleotide analogues exhibit potent in vitro activity against flaviviridae NTPases/helicases, including those of the West Nile virus, hepatitis C virus, and Japanese encephalitis virus. J. Med. Chem. 2003, 46, 4149-4164.

108. Borowski, P.; Lang, M.; Haag, A.; Schmitz, H.; Choe, J.; Chen, H.M.; Hosmane, R.S. Characterization of imidazo[4,5-d]pyridazine nucleosides as modulators of unwinding reaction mediated by West Nile virus nucleoside triphosphatase/helicase: Evidence for activity on the level of substrate and/or enzyme. Antimicrob. Agents Chemother. 2002, 46, 1231-1239. 
109. Munoz-Jordan, J.L.; Laurent-Rolle, M.; Ashour, J.; Martinez-Sobrido, L.; Ashok, M.; Lipkin, W.I.; Garcia-Sastre, A. Inhibition of Alpha/Beta interferon signaling by the NS4B protein of flaviviruses. J. Virol. 2005, 79, 8004-8013.

110. Puig-Basagoiti, F.; Tilgner, M.; Bennett, C.J.; Zhou, Y.; Muñoz-Jordán, J.L.; García-Sastre, A.; Bernard, K.A.; Shi, P.Y. A mouse cell-adapted NS4B mutation attenuates West Nile virus RNA synthesis. Virology 2007, 361, 229-341.

111. Wicker, J.A.; Whiteman, M.C.; Beasley, D.W.; Davis, C.T.; Zhang, S.; Schneider, B.S.; Higgs, S.; Kinney, R.M.; Barrett, A.D. A single amino acid substitution in the central portion of the West Nile virus NS4B protein confers a highly attenuated phenotype in mice. Virology 2006, 349, 245-253.

112. Welte, T.; Xie, G.; Wicker, J.A.; Whiteman, M.C.; Li, L.; Rachamallu, A.; Barrett, A.; Wang, T. Immune responses to an attenuated West Nile virus NS4B-P38G mutant strain. Vaccine 2011, 29, 4853-4861.

113. Xie, X.; Wang, Q.Y.; Xu, H.Y.; Qing, M.; Kramer, L.; Yuan, Z.; Shi, P.Y. Inhibition of dengue virus by targeting viral NS4B protein. J. Virol. 2011, 85, 11183-11195.

114. Van Cleef, K.W.; Overheul, G.J.; Thomassen, M.C.; Kaptein, S.J.; Davidson, A.D.; Jacobs, M.; Neyts, J.; van Kuppeveld, F.J.; van Rij, R.P. Identification of a new dengue virus inhibitor that targets the viral NS4B protein and restricts genomic RNA replication. Antivir. Res. 2013, 99, 165-171.

115. Zou, G.; Puig-Basagoiti, F.; Zhang, B.; Qing, M.; Chen, L.; Pankiewicz, K.W.; Felczak, K.; Yuan, Z.; Shi P.Y. A single-amino acid substitution in West Nile virus 2K peptide between NS4A and NS4B confers resistance to lycorine, a flavivirus inhibitor. Virology 2009, 384, 242-252.

116. Patkar, C.G.; Larsen, M.; Owston, M.; Smith, J.L.; Kuhn, R.J. Identification of inhibitors of yellow fever virus replication using a replicon-based high-throughput assay. Antimicrob. Agents Chemother. 2009, 53, 4103-4114.

117. Bollati, M.; Alvarez, K.; Assenberg, R.; Baronti, C.; Canard, B.; Cook, S.; Coutard, B.; Decroly, E.; de Lamballerie, X.; Gould, E.A.; et al. Structure and functionality in flavivirus NS-proteins: Perspectives for drug design. Antivir. Res. 2010, 87, 125-148.

118. Noble, C.G.; Shi, P.Y. Structural biology of dengue virus enzymes: Towards rational design of therapeutics. Antivir. Res. 2012, 96, 115-126.

119. Lescar, J.; Lim, S.P.; Shi, P. Molecular Virology and Control of Flaviviruses; Shi P., Ed.; Caister Academic Press: Norfolk, UK, 2012; Chapter 6, p. 101.

120. Davidson, A.D. New insights into Flavivirus nonstructural protein 5. Adv. Virus Res. 2009, 74, 41-101.

121. Dong, H.; Zhang, B.; Shi, P.Y. Flavivirus methyltransferase: A novel antiviral target. Antivir. Res. 2008, 80, 1-10.

122. Zhou, Y.; Ray, D.; Zhao, Y.; Dong, H.; Ren, S.; Li, Z.; Guo, Y.; Bernard, K.; Shi, P.Y.; Li, H. Structure and function of flavivirus NS5 methyltransferase. J. Virol. 2007, 81, 3891-3903.

123. Daffis, S.; Szretter, K.J.; Schriewer, J.; Li, J.; Youn, S.; Errett, J.; Lin, T.Y.; Schneller, S.; Zust, R.; Dong, H.; et al. 2'-O methylation of the viral mRNA cap evades host restriction by IFIT family members. Nature 2010, 468, 452-456. 
124. Dong, H.; Chang, D.C.; Hua, M.H.; Lim, S.P.; Chionh, Y.H.; Hia, F.; Lee, Y.H.; Kukkaro, P.; Lok, S.-M.; Dedon, P.C.; et al. 2'-O Methylation of Internal Adenosine by Flavivirus NS5 Methyltransferase. PLoS Patho. 2012, 8, 1-12.

125. Issur, M.; Geiss, B.J.; Bougie, I.; Picard-Jean, F.; Despins, S.; Mayette, J.; Hobdey, S.E.; Bisaillon, M. The flavivirus NS5 protein is a true RNA guanylyltransferase that catalyzes a two-step reaction to form the RNA cap structure. RNA 2009, 15, 2340-2350.

126. Bollati, M.; Milani, M.; Mastrangelo, E.; Ricagno, S.; Tedeschi, G.; Nonnis, S.; Decroly, E.; Selisko, B.; de Lamballerie, X.; Coutard, B.; et al. Recognition of RNA cap in the Wesselsbron virus NS5 methyltransferase domain: Implications for RNA-capping mechanisms in Flavivirus. J. Mol. Biol. 2009, 385, 40-52.

127. Podvinc, M.; Lim, S.P.; Schmidt, T.; Scarsi, M.; Wen, D.; Sonntag, L.S.; Sanschagrin, P.; Shenkin, P.S.; Schwede, T. Novel inhibitors of dengue virus methyltransferase: Discovery by in vitro-driven virtual screening on a desktop computer grid. J. Med. Chem. 2010, 53, 1483-1495.

128. Dong, H.; Liu, L.; Zou, G.; Zhao, Y.; Li, Z.; Lim, S.P.; Shi, P-Y.; Li., H. Structural and Functional Analyses of a Conserved Hydrophobic Pocket of Flavivirus Methyltransferase. J. Biol. Chem. 2010, 285, 32586-32595.

129. Lim., S.P.; Sonntag., L.S.; Noble, C.; Nilar, S.H.; Ng, R.H.; Zou, G.; Monaghan, P.; Chung, K.Y.; Dong, H.; Liu, B.; et al. Small molecule inhibitors that selectively block dengue virus methyltransferase. J. Biol. Chem. 2010, 286, 6233-6240.

130. Geiss, B.J.; Stahla-Beek, H.J.; Hannah, A.M.; Gari, H.H.; Henderson, B.R.; Saeedi, B.J.; Keenan, S.M. A high-throughput screening assay for the identification of flavivirus NS5 capping enzyme GTP-binding inhibitors: Implications for antiviral drug development. J. Biomol. Screen. 2011, 16, 852-861.

131. Stahla-Beek, H.J.; April, D.G.; Saeedi, B.J.; Hannah, A.M.; Keenan, S.M.; Geiss, B.J. Identification of a novel antiviral inhibitor of the flavivirus guanylyltransferase enzyme. J. Virol. 2012, 86, 8730-8739.

132. Delang, L.; Vliegen, I.; Froeyen, M.; Neyts, J. Comparative study of the genetic barriers and pathways towards resistance of selective inhibitors of hepatitis $\mathrm{C}$ virus replication. Antimicrob. Agents Chemother. 2011, 55, 4103-4113.

133. Ojwang, J.O.; Ali, S.; Smee, D.F.; Morrey, J.D.; Shimasaki, C.D.; Sidwell, R.W. Broad-spectrum inhibitor of viruses in the Flaviviridae family. Antivir. Res. 2005, 68, 49-55.

134. Yin, Z.; Chen, Y.L.; Schul, W.; Wang, Q.Y.; Gu, F.; Duraiswamy, J.; Kondreddi, R.R.; Niyomrattanakit, P.; Lakshminarayana, S.B.; Goh, A.; et al. An adenosine nucleoside inhibitor of dengue virus. Proc. Natl. Acad. Sci. USA 2009, 106, 20435-20439.

135. Chen, Y.L.; Yin, Z.; Lakshminarayana, S.B.; Qing, M.; Schul, W.; Duraiswamy, J.; Kondreddi, R.R.; Goh, A.; Xu, H.Y.; Yip, A.; et al. Inhibition of dengue virus by an ester prodrug of an adenosine analog. Antimicrob. Agents Chemother. 2010, 20154, 3255-3261.

136. Migliaccio, G.; Tomassini, J.E.; Carroll, S.S.; Tomei, L.; Altamura, S.; Bhat, B.; Bartholomew, L.; Bosserman, M.R.; Ceccacci, A.; Colwell, L.F.; et al. Characterization of resistance to non-obligate chain-terminating ribonucleoside analogs that inhibit hepatitis $\mathrm{C}$ virus replication in vitro. J. Biol. Chem. 2003, 278, 49164-49170. 
137. Nguyen, N.M.; Tran, C.N.; Phung, L.K.; Duong, K.T.; Huynh, H.L.; Farrar, J.; Nguyen, Q.T.; Tran, H.T.; Nguyen, C.V.; Merson, L.; et al. A randomized, double-blind placebo controlled trial of balapiravir, a polymerase inhibitor, in adult dengue patients. J. Infect. Dis. 2013, 207, 1442-1450.

138. Ono, L.; Wollinger, W.; Rocco, I.M.; Coimbra, T.L.M.; Gorin, P.A.J.; Sierakowski, M.-R. In vitro and in vivo antiviral properties of sulfated galactomannans against yellow fever virus (BeH111 strain) and dengue 1 virus (Hawaii strain). Antivir. Res. 2003, 60, 201-208.

139. Malet, H.; Egloff, M.P.; Selisko, B.; Butcher, R.E.; Wright, P.J.; Roberts, M.; Gruez, A.; Sulzenbacher, G.; Vonrhein, C.; Bricogne, G.; et al. Crystal structure of the RNA polymerase domain of the West Nile virus non-structural protein 5. J. Biol. Chem. 2007, 282, 10678-10689.

140. Selisko, B.; Dutartre, H.; Guillemot, J.C.; Debarnot, C.; Benarroch, D.; Khromykh, A.A.; Despres, P.; Egloff, M.P.; Canard, B. Comparative mechanistic studies of de novo RNA synthesis by flavivirus RNA-dependent RNA polymerases. Virology 2006, 351, 145-158.

141. Nomaguchi, M.; Teramoto, T.; Yu, L.; Markoff, L.; Padmanabhan, R. Requirements for West Nile virus (-)- and (+)-strand subgenomic RNA synthesis in vitro by the viral RNA-dependent RNA polymerase expressed in Escherichia coli. J. Biol. Chem. 2004, 279, 12141-12151.

142. Niyomrattanakit, P.; Chen, Y.L.; Dong, H.; Yin, Z.; Qing, M.; Glickman, J.F.; Lin, K.; Mueller, D.; Voshol, H.; Lim, J.Y; et al. Inhibition of dengue virus polymerase by blocking of the RNA tunnel. J. Virol. 2010, 84, 5678-5686.

143. Malet, H.; Massé, N.; Selisko, B.; Romette, J.L.; Alvarez, K.; Guillemot, J.C.; Tolou, H.; Yap, T.L.; Vasudevan, S.; Lescar, J.; et al. The flavivirus polymerase as a target for drug discovery. Antivir. Res. 2008, 80, 23-35.

144. Zou, G.; Chen, Y.L.; Dong, H.; Lim, C.C.; Yap, L.J.; Yau, Y.H.; Shochat, S.G.; Lescar, J.; Shi, P.Y. Functional analysis of two cavities in flavivirus NS5 polymerase. J. Biol. Chem. 2011, 286, 14362-14372.

145. Noble, C.G.; Lim, S.P.; Chen, Y.L.; Liew, C.W.; Yap, L.; Lescar, J.; Shi, P.Y. Conformational flexibility of the Dengue virus RNA-dependent RNA polymerase revealed by a complex with an inhibitor. J. Virol. 2013, 87, 5291-5295.

146. Schang, L.M. First demonstration of the effectiveness of inhibitors of cellular protein kinases in antiviral therapy. Expert Rev. Anti-Infect. Ther. 2006, 4, 953-956.

147. Hayes, E.B.; Sejvar, J.J.; Zaki, S.R.; Lanciotti, R.S.; Bode, A.V.; Campbell, G.L. Virology, pathology, and clinical manifestations of West Nile virus disease. Emerg. Infect. Dis. 2005, 11, 1174-1179.

148. Davis, L.E.; DeBiasi, R.; Goade, D.E.; Haaland, K.Y.; Harrington, J.A.; Harnar, J.B.; Pergam, S.A.; King, M.K.; DeMasters, B.K.; Tyler, K.L. West Nile virus neuroinvasive disease. Ann. Neurol. 2006, 60, 286-300.

149. Wang, Q.Y.; Kondreddi, R.R.; Xie, X.; Rao, R.; Nilar, S.; Xu, H.Y.; Qing, M.; Chang, D.; Dong, H.; Yokokawa, F.; et al. A translation inhibitor that suppresses dengue virus in vitro and in vivo. Antimicrob. Agents Chemother. 2011, 55, 4072-4080.

150. Noueiry, A.O.; Olivo, P.D.; Slomczynska, U.; Zhou, Y.; Buscher, B.; Geiss, B.; Engle, M.; Roth, R.M.; Chung, K.M.; Samuel, M.; et al. Identification of novel small-molecule inhibitors of West Nile virus Infection. J. Virol. 2007, 81, 11992-12004. 
151. Michaelis, M.; Kleinschmidt, M.C.; Doerr, H.W.; Cinatl, J., Jr. Minocycline inhibits West Nile virus replication and apoptosis in human neuronal cells. Antimicrob. Chemother. 2007, 60, 981-986.

152. Qing, M.; Yang, F.; Zhang, B.; Zou, G.; Robida, J.M.; Yuan, Z.; Tang, H.; Shi, P.Y. Cyclosporine inhibits flavivirus replication through blocking the interaction between host cyclophilins and viral NS5 protein. Antimicrob. Agents Chemother. 2009, 53, 3226-3235.

153. Diamond, M.S.; Zachariah, M.; Harris, E. Mycophenolic acid inhibits dengue virus infection by preventing replication of viral RNA. Virology 2002, 304, 211-221.

154. Morrey, J.; Smee, D.; Sidwell, R.; Tseng, C. Identification of active antiviral compounds against a New York isolate of West Nile virus. Antivir. Res. 2002, 55, 107-116.

155. Leyssen, P.; Balzarini, J.; de Clercq, E.; Neyts, J. The predominant mechanism by which ribavirin exerts its antiviral activity in vitro against flaviviruses and paramyxoviruses is mediated by inhibition of IMP dehydrogenase. J. Virol. 2005, 79, 1943-1947.

156. Thomas, E.; Feld, J.J.; Li, Q.; Hu, Z.; Fried, M.W.; Liang, T.J. Ribavirin potentiates interferon action by augmenting interferon-stimulated gene induction in hepatitis $\mathrm{C}$ virus cell culture models. Hepatology 2011, 53, 32-41.

157. Pan, Q.; de Ruiter, P.E.; Metselaar, H.J.; Kwekkeboom, J.; de Jonge, J.; Tilanus, H.W.; Janssen, H.L.; van der Laan, L.J. Mycophenolic acid augments interferon-stimulated gene expression and inhibits hepatitis C Virus infection in vitro and in vivo. Hepatology 2012, 55, 1673-1683.

158. Crance, J.M.; Scaramozzino, N.; Jouan, A.; Garin, D. Interferon, ribavirin, 6-azauridine and glycyrrhizin: Antiviral compounds active against pathogenic flaviviruses. Antivir. Res. 2003, 58, 73-79.

159. Wang, Q.Y.; Bushell, S.; Qing, M.; Xu, H.Y.; Bonavia, A.; Nunes, S.; Zhou, J.; Poh, M.K.; Florez de Sessions, P.; Niyomrattanakit, P.; et al. Inhibition of dengue virus through suppression of host pyrimidine biosynthesis. J. Virol. 2011, 85, 6548-6556.

160. Qing, M.; Zou, G.; Wang, Q.Y.; Xu, H.Y.; Dong, H.; Yuan, Z.; Shi, P.Y. Characterization of dengue virus resistance to brequinar in cell culture. Antimicrob. Agents Chemother. 2010, 54, 3686-3695.

161. Durantel, D. Celgosivir, an alpha-glucosidase I inhibitor for the potential treatment of HCV infection. Curr. Opin. Investig. Drugs. 2009, 10, 860-870.

162. Whitby, K.; Pierson, T.C.; Geiss, B.; Lane, K.; Engle, M.; Zhou, Y.; Doms, R.W.; Diamond, M.S. Castanospermine, a potent inhibitor of dengue virus infection in vitro and in vivo. J. Virol. 2005, 79, 8698-8706.

163. Rathore, A.P.; Paradkar, P.N.; Watanabe, S.; Tan, K.H.; Sung, C.; Connolly, J.E.; Low, J.; Ooi, E.E.; Vasudevan, S.G. Celgosivir treatment misfolds dengue virus NS1 protein, induces cellular pro-survival genes and protects against lethal challenge mouse model. Antivir. Res. 2011, 92, 453-460.

164. Watanabe, S.; Rathore, A.P.; Sung, C.; Lu, F.; Khoo, Y.M.; Connolly, J.; Low, J.; Ooi, E.E.; Lee, H.S.; Vasudevan, S.G. Dose- and schedule-dependent protective efficacy of celgosivir in a lethal mouse model for dengue virus infection informs dosing regimen for a proof of concept clinical trial. Antivir. Res. 2012, 96, 32-35. 
165. Gu, B.; Mason, P.; Wang, L.; Norton, P.; Bourne, N.; Moriarty, R.; Mehta, A.; Despande, M.; Shah, R.; Block, T. Antiviral profiles of novel iminocyclitol compounds against bovine viral diarrhea virus, West Nile virus, dengue virus and hepatitis B virus. Antivir. Chem. Chemother. 2007, 18, 49-59.

166. Chang, J.; Wang, L.; Ma, D.; Qu, X.; Guo, H.; Xu, X.; Mason, P.M.; Bourne, N.; Moriarty, R.; $\mathrm{Gu}, \mathrm{B}$; et al. Novel imino sugar derivatives demonstrate potent antiviral activity against flaviviruses. Antimicrob. Agents Chemother. 2009, 53, 1501-1508.

167. Xu, Z.; Anderson, R.; Hobman, T.C. The capsid-binding nucleolar helicase DDX56 is important for infectivity of West Nile virus. J. Virol. 2011, 85, 5571-5580.

168. Xu, Z.; Hobman, T.C. The helicase activity of DDX56 is required for its role in assembly of infectious West Nile virus particles. Virology 2012, 433, 226-235.

169. Hirsch, A.J.; Medigeshi, G.R.; Meyers, H.L.; DeFilippis, V.; Früh, K.; Briese, T.; Lipkin, W.I.; Nelson, J.A. The Src family kinase c-Yes is required for maturation of West Nile virus particles. J. Virol. 2005, 79, 11943-11951.

170. Becker, G.L.; Lu, Y.; Hardes, K.; Strehlow, B.; Levesque, C.; Lindberg, I.; Sandvig, K.; Bakowsky, U.; Day, R.; Garten, W.; et al. Highly potent inhibitors of proprotein convertase furin as potential drugs for treatment of infectious diseases. J. Biol. Chem. 2012, 287, 21992-22003.

171. Murray, K.O.; Walker, C.; Gould, E. The virology, epidemiology, and clinical impact of West Nile virus: A decade of advancements in research since its introduction into the Western Hemisphere. Epidemiol. Infect. 2011, 139, 807-817.

172. Najera, I. Resistance to HCV nucleoside analogue inhibitors of hepatitis C virus RNA-dependent RNA polymerase. Curr. Opin. Virol. 2013, 3, 508-513.

(C) 2013 by the authors; licensee MDPI, Basel, Switzerland. This article is an open access article distributed under the terms and conditions of the Creative Commons Attribution license (http://creativecommons.org/licenses/by/3.0/). 